IZA DP No. 4266

The Height Premium in Earnings:

The Role of Physical Capacity and Cognitive and Non-Cognitive Skills

Petter Lundborg

Paul Nystedt

Dan-Olof Rooth

June 2009 


\title{
The Height Premium in Earnings: The Role of Physical Capacity and Cognitive and Non-Cognitive Skills
}

\author{
Petter Lundborg \\ VU University Amsterdam, Tinbergen Institute, \\ Netspar, HEP, CED and IZA \\ Paul Nystedt \\ Linköping University and HEP \\ Dan-Olof Rooth \\ Kalmar University, Lund University, \\ CReAM and IZA
}
Discussion Paper No. 4266
June 2009

\author{
IZA \\ P.O. Box 7240 \\ 53072 Bonn \\ Germany \\ Phone: +49-228-3894-0 \\ Fax: +49-228-3894-180 \\ E-mail: iza@iza.org
}

\begin{abstract}
Any opinions expressed here are those of the author(s) and not those of IZA. Research published in this series may include views on policy, but the institute itself takes no institutional policy positions.

The Institute for the Study of Labor (IZA) in Bonn is a local and virtual international research center and a place of communication between science, politics and business. IZA is an independent nonprofit organization supported by Deutsche Post Foundation. The center is associated with the University of Bonn and offers a stimulating research environment through its international network, workshops and conferences, data service, project support, research visits and doctoral program. IZA engages in (i) original and internationally competitive research in all fields of labor economics, (ii) development of policy concepts, and (iii) dissemination of research results and concepts to the interested public.
\end{abstract}

IZA Discussion Papers often represent preliminary work and are circulated to encourage discussion. Citation of such a paper should account for its provisional character. A revised version may be available directly from the author. 


\section{ABSTRACT \\ The Height Premium in Earnings: The Role of Physical Capacity and Cognitive and Non-Cognitive Skills ${ }^{*}$}

The association between stature and favorable labor market outcomes has been extensively documented. Recent studies have attributed this height premium to cognitive and social skills. We offer an alternative explanation, where the premium mainly arises from the positive association between height and physical capacity. Accounting for the latter reduces the height premium by about 80 percent. By also accounting for cognitive and non-cognitive skills, we are able to explain the entire height premium. Our estimates are based on data from the military enlistment register that has been linked to earnings for the entire population of Swedish males aged 28-38 in 2003.

JEL Classification: $\quad \mathrm{J} 10, \mathrm{~J} 70$

Keywords: earnings, height premium, cognitive and non-cognitive skills, physical capacity

Corresponding author:

Dan-Olof Rooth

Department of Economics

Kalmar University College

39182 Kalmar

Sweden

E-mail: Dan-Olof.Rooth@hik.se

\footnotetext{
* We thank seminar participants at the workshop in labor economics held in March 2009 at IFAU (Uppsala), at Växjö University, and at the ESPE 2009 conference in Seville for helpful suggestions. A research grant from the Centre for Economic Demography at Lund University is gratefully acknowledged.
} 


\section{Introduction}

The association between height and social status is one of the most consistent findings in the social sciences. It has been obtained using eighteenth-century data from Germany as well as using US and UK data from recent years (Komlos et al. 1992; Persico et al. 2004; Case and Paxson 2008a). Despite being widely documented, the debate continues about the extent to which this premium reflects certain inherent personal productivity enhancing characteristics that are associated with height and to what extent it reflects pure discrimination against shorter individuals (Steckel 2009).

In developing countries, where jobs are relatively more dominated by manual and physically demanding tasks, the height premium has been attributed to the greater physical capacity that follows from greater height (e.g. Steckel 1995, Dinda et al. 2006, Thomas and Strauss 1997). For the western world, where fewer jobs are physically demanding, recent studies have attributed the height premium to cognitive and noncognitive skills that are associated with height (Persico et al. 2004; Case and Paxson 2008a). In their analysis of data from the UK and US (National Child Development Study, NCDS and National Longitudinal Survey of Youth, NLSY, respectively), Persico et al. (2004) find that teen height essentially explains the full association between adult height and hourly wages, among white men. In addition, they find that childhood cognitive test scores do not affect the estimated height premium, but rather that the link between teen height and later life earnings runs via participation in activities that build social skills and social capital during adolescence. Case and Paxson (2008a) use the same data and find that cognitive ability measured in childhood and youth explains 30\%-50\% of the height premium. ${ }^{1}$ Hence, the explanations differ in the two studies, partly reflecting differences in the selection of their samples. Also, in both studies, a substantial height premium remains, although being statistically insignificant, after accounting for cognitive skills or participation in social activities and, hence, there is to date no consensus on which factors that fully explain the height premium.

\footnotetext{
${ }^{1}$ A number of other studies have examined the impact of stature on labor market outcomes. While these essentially find a positive impact they commonly group height into distinct categories; e.g. "tall", "medium" and "short", see Loh (1993), Hamermesh and Biddle (1994), and Harper (2000), or are based on few observations, see e.g. Behrman and Rosenzweig (2001), which makes comparisons of result difficult.
} 
In this study, we set out to explain the height premium in earnings using large scale register data with information on individual cognitive skills, non-cognitive skills, and physical capacity. The latter is a personal characteristic that has been more or less ignored in the previous studies on the height premium in developed societies. ${ }^{2}$ Our analysis is based on data from the Swedish military enlistment records on 450,000 men, undergoing mandatory enlistment for the Swedish military at age 18 and being 28-38 years of age in 2003. The data also covers register information on earnings in 2003, as well as parental information on schooling and earnings. In addition, we are able to identify 145,000 siblings in the data, allowing us to account for unobserved heterogeneity at the family-level through the use of family fixed effects.

We find that, taken separately, both cognitive and non-cognitive skills explain about one third of the height premium, which corresponds fairly well to the results obtained by Persico et al (2004) and Case and Paxson (2008a). However, we also find that physical capacity explains about 80 percent of the height premium. Including both physical capacity and the skill variables in the earnings equation, we are able to explain the entire height premium.

This paper is organized as follows. Section 2 discusses how cognitive and noncognitive skills and physical capacity may be linked to height, thereby potentially explaining parts of a height premium in earnings. In Section 3 we describe our data and method, and provide some descriptive statistics, while our results are presented in Section 4. These results are then discussed in Section 5.

\section{Height, skills, physical capacity, and earnings}

\subsection{Height and physical capacity}

It has long been known that anthropometric measures such as body height are strongly correlated with measures of physical capacity, such as muscular strength (see e.g. Everett and Sills 1952 for an early example). If physical capacity is rewarded in the labor market,

\footnotetext{
${ }^{2}$ A variable measuring health condition is included in Persico et al. (2004), but it rather reflects health extremes in terms of slight, moderate, or severe motor handicap, mental retardation, upper/lower limb abnormality, diabetes etc. and does not affect the height premium. Case and Paxson (2008a) include measures of birth weight and parental smoking.
} 
the height premium may therefore partly reflect the rewards to physical capacity. One would be inclined to believe, however, that economic development reduces the direct importance of characteristics such as muscular strength and endurance in the production process in modern industrialized countries. Instead, it seems conceivable that cognitive and non-cognitive skills to an increasing extent are becoming related to productivity. This does not necessarily mean that physical capacity is an unimportant trait. First of all, physical capacity is strongly related to adult health and may therefore be indirectly rewarded in the labor market. In various populations, muscular strength has been found to predict lower total mortality and mortality from cancer and respiratory diseases (Metter et al. 2002; Gale et al. 2007; Wijndaele et al. 2007). In a similar vein, physical capacity, often measured through cardiorespiratory capacity, has consistently been associated with lowered risk of premature deaths from mainly cardiovascular diseases and to a lesser extent with lowered risk of cancer-related mortality (Ekelund et al. 1988; Slattery and Jacobs 1988; Blair et al. 1989; Sandvik et al. 1993). It is therefore not farfetched to assume that physical capacity may act as a signal of good health for employers and that the height premium partly reflects the greater physical capacity that comes with greater height.

Moreover, technological advancements have not completely removed physically demanding jobs in western countries. Certain blue-collar occupations, such as construction, mining, and waste management, for example, still require a certain amount of muscular strength and endurance. Some jobs in the manufacturing industry and the health care sector also involve strenuous physical motion, and monotonic and/or nonergonomic movements that may induce injuries. In these type of jobs, it is thus likely that physical capacity is directly related to productivity. This would, in turn, imply that physical capacity is mostly rewarded in the lower end of the earnings distribution, where jobs may still be physically demanding. It is therefore of importance to examine the extent to which the height premium is explained by physical capacity at different points within the earnings distribution.

To the extent that physical capacity is visible to the employer, it may also signal certain attractive personality traits. Physical strength, for instance, is related to regular exercise and may therefore signal demanded traits, such as self-control, patience, 
persistence, and motivation. In a recent study, males with higher scores on strength tests were also found to be more aggressive and dominant (Gallup et al. 2007). In addition, physical strength seems to be related to attractiveness. In a recent study by Fink et al. (2007), female participants rated the attractiveness of males based on facial photos. The results showed that rated attractiveness was correlated with the rated subjects' handgrip strength, used as a measure of overall physical strength. ${ }^{3}$ Hence, it is possible that measures of physical capacity (and especially handgrip strength) relate not only to muscular function and endurance, but also to facial characteristics and attractiveness, which in turn is rewarded in the labor market.

Summarizing, there are multiple reasons why physical capacity would be rewarded even in modern countries where work has become more sedimentary and less dependent on physical capacity. Since height is known to correlate with physical capacity, it therefore also seems reasonable that the height premium to some extent reflects the returns to physical capacity. What are then the mechanisms underlying the positive correlation between height and physical capacity? One explanation would be that the development of the muscular system and physical capacity is related to the same genetic predispositions and susceptible to the same environmental conditions as height growth, thereby yielding a positive correlation between the two. This is also suggested in a recent study by Silventoinen et al. (2008), who showed that genetic factors affect muscle strength and that some genes are common to both different strength indicators and body height. Related to this are findings suggesting an important role of early life conditions for both the development of muscle strength and height. For the former outcome, a number of studies have shown a positive association between birth weight and adult muscle mass, muscle metabolism, and muscle strength (Philips 1995; Gale et al. 2001; Kahn et al. 2000). ${ }^{4}$ Several studies also find an association between birth weight and

\footnotetext{
${ }^{3}$ In line with this, Gallup et al. (2007) found that grip strength was associated with "increased sexual opportunities," resulting in an increased number of sexual partners, and younger ages of first sexual encounter. One explanation for this is that certain genes increase testosterone levels, which also increases muscle mass. The result was only obtained among males.

${ }^{4}$ The associations obtained could also be explained by the skeletal size effects, since taller persons also tend to have larger muscles. Richards et al. (2002), however, showed that this association remained after adjusting for adult height.
} 
adult height. The strongest evidence comes from twin studies, such as Black et al. (2007), where differences in adult height between identical twins are related to differences in their birth weights. Also using data on identical twins, Behrman and Rosenzweig (2004) obtained a positive association between fetal growth and height in adulthood. In a recent study, van den Berg et al. (2009) obtained evidence suggesting that improvements in living conditions during certain ages during childhood have causal effects on height as an adult.

\subsection{Height and cognitive and non-cognitive skills}

A positive association between height and cognitive ability has been documented in numerous studies (Richards et al. 2002, Case and Paxson 2008a, 2008b). This association was exploited by Case and Paxson (2008a) and formed the basis for their argument that the height premium in earnings to a large extent reflects the fact that taller people on average have greater cognitive abilities. ${ }^{5}$ The authors also provide an excellent survey of some of the potential explanations for the positive association between height and cognitive ability. Summarizing, it is postulated that certain growth factors are related to both height and cognitive ability, though there is still substantial uncertainty regarding the exact underlying mechanisms. For instance, insulin-like growth factors are believed to influence body growth while at the same time influencing areas in the brain where cognition occurs. It is also assumed that environmental factors, such as maternal smoking during pregnancy, may explain part of the association between height and cognition. It should be noted that the study by Black et al. (2007) also found a connection between birth weight and IQ test scores, again underscoring the importance of the intrauterine environment for adult height as well as cognitive ability.

Much less is known about the relation between height and non-cognitive skills. Noncognitive skill is commonly referred to in the literature as personal character traits such as motivation, sociability (the capability of interacting and working with others), persistence, time preference (the ability or will to postpone instant pleasures in favor of

\footnotetext{
${ }^{5}$ The importance of cognitive skills for successful labor market outcomes is well established (see e.g. Cawley et al. 2001).
} 
future returns), and charm. In the labor economics literature the term essentially describes a complexity of personal characteristics connected to the aspects of one's personality, potentially affecting productivity, but distinct from cognitive skill. It seems uncontroversial to presume that non-cognitive abilities are valued by employers, coworkers and potential customers in almost any kind of occupation. Indeed, a recent body of research has shown that non-cognitive skills are important predictors of various adult socioeconomic outcomes (see e.g. Heckman and Rubinstein 2001; Heckman et al. 2006). In fact, some studies suggest that non-cognitive skills are at least as important as cognitive skill in determining earnings and employment (Heckman et al. 2006; Heckman 2008; Borghans et al. 2008). If height is related to non-cognitive skills, it is therefore straightforward to formulate a hypothesis where part of the height premium simply reflects the returns to non-cognitive skills, similar in spirit to the Case and Paxson (2008a) argument regarding cognitive skills.

Whereas the linkage between cognition and height has been attributed mainly to biological processes early in life, the connection between non-cognitive skills and height has mainly been attributed to social processes. These social processes are usually believed to stem from the fact that taller people are treated differently than shorter people in ways that facilitate the formation of non-cognitive skills. For instance, a common theory in social psychology is that taller people are more successful for reasons of interpersonal dominance (see e.g. Frieze et al. 1990). It then follows that if height is of advantage in negotiation situations, this may facilitate the building of self-esteem and social skills in tall people. Moreover, tall children may face different expectations from parents, teachers, other adults, and peers. As discussed by Persico et al. (2004), another explanation emphasizes the role of self-esteem, but from a different perspective. Here, the height premium stems from the greater self-image that is achieved through a comparison with a socially determined notion of ideal height. It is then argued that a greater self-image leads to higher achievement through non-cognitive factors such as perseverance and social skills. This is related to the findings of Persico et al. (2004), where teen height is found to explain a large part of the height premium in earnings, and where the premium is reduced when controlling for participation in high school sports and clubs. The latter finding causes the authors to conclude that such participation shapes 
non-cognitive skills. In sum, existing explanations for the association between height and non-cognitive skills in general focus on how height may affect the development of noncognitive skills, rather than both being determined by some third, underlying factor.

\section{Data, method and descriptive statistics}

Our empirical analysis is based on a data set constructed by integrating registers from Statistics Sweden (SCB) and the Swedish National Service Administration. The latter contains information on every individual living in Sweden in the year 1999 who enlisted for the military between 1984 and $1997 .{ }^{6}$ Our study population consists of all males who were 28-38 years old in 2003, who enlisted for the military, and for whom there is full information on relevant variables. Enlisting for the military is carried out during a twoday procedure and is mandatory for all male Swedish citizens the year they turn 18. Only persons with severe handicap, institutionalized persons (both due to mental disorders or being in prison), or persons living abroad are exempted from enlisting. ${ }^{7}$ It should also be noted that a refusal to enlist results in fines, and eventually in imprisonment. In order to avoid any confounding influence of ethnic discrimination, we restrict our analyses to native Swedish males, i.e., those born in Sweden to Swedish-born parents. ${ }^{8}$ Given these restrictions, our study population covers about 92 percent of the total native male Swedish population in the relevant cohorts.

Our base sample consists of 468,312 individuals. Out of these, 96 percent had positive annual earnings in 2003, i.e., 448,702 individuals, which is the sample that we use in our analyses. Hence, there is very little attrition in the data and it more or less covers the entire native born male Swedish population. In some parts of the analysis we instead focus on variation between siblings, which reduces the sample being analyzed to 145,210 individuals. Since the enlistment variables are measured by military personnel,

\footnotetext{
${ }^{6}$ The individuals had to live in Sweden during 1999, since many important variables, e.g. the enlistment information and the family information, are collected for the 1999 population data.

${ }^{7}$ Since the persons in our sample enlisted during the years 1984-1997, and since earnings are followed up in 2003, this implies that we lose a small number of people due to death and emigration. There is no information available on why a particular individual did not enlist.

${ }^{8}$ Moreover, non-native ethnic groups have a much lower participation rate for enlisting since only about fifty percent (or less) are Swedish citizens, making selective participation an issue for these groups.
} 
and earnings by tax authorities, our results are not influenced by any reporting bias, which often plagues survey data.

Our measure of annual earnings includes income from work, self-employed income and social insurance benefits such as sickness benefits, child allowance and parental benefits for the year 2003 and is taken from the tax records. A sensitivity analysis conducted in Section 4.2.2, where only income from work and self-employed income is included in the measure of earnings, shows that the inclusion of social insurance benefits does not affect our results.

Cognitive skill is measured using a test similar in style to the AFQT in the US. The name of the test is Enlistment Battery 80 and it includes four separate tests, Instructions, Synonyms, Metal Folding, and Technical Comprehension. The cognitive skill variable used in the analysis is a standardized version of the composite cognitive measure calculated by the military enlistment service, which ranges from 1 to $9 .^{9}$

Non-cognitive skills are measured through interviews carried out by certified psychologists. ${ }^{10}$ The interview is intended to contain assessments of psychological stability and endurance, capability of taking initiative, responsibility, and social competence. The ultimate purpose of the interview is to evaluate the conscript's ability to perform military service and to function in a war situation. This evaluation results in a composite enlistment score of non-cognitive skills, ranging from 1 to 9 , which we then standardize in our analyses.

Moreover, enlistees scoring 5 or above on the cognitive test are also evaluated by the psychologist concerning their "leadership skills". Since only part of the sample is evaluated on this specific trait, we will use it as a complement to the more universal noncognitive skill measure. It should be noted that the scores obtained for leadership skills and non-cognitive skills are strongly correlated $(r=0.88)$.

\footnotetext{
${ }^{9}$ The general intelligence factor, $G$, is the variable used in this study. For more information about the $G$ factor, see Carroll (1993). The separate tests and the composite measure have a correlation of above 0.9.

${ }^{10}$ Exact details of this part of the enlistment process are not publically revealed and we are merely referred to information on the intentions of the assessment procedure. It should be noted that our measure of noncognitive ability is a strong predictor of earnings, independently of cognitive skills.
} 
Though the original purpose of the non-cognitive skill measure used here is to evaluate peoples' suitability to serve in a war situation, it seems reasonable to assume that the character traits valued by the military psychologists (psychological stability and endurance, capability of taking initiatives, responsibility and social competence etc.) may also be appreciated and rewarded in the labor market.

In order to measure physical capacity, we make use of test scores on muscular strength and physical work capacity. Muscular strength is measured by handgrip strength, which is measured as the maximum pressure exerted by one hand squeezing a bar. Grip strength is a common method for assessing overall muscle strength (e.g. Fujita et al. 1995; Metter et al. 2002; Gale et al. 2007). Besides muscle strength, we will include a measure of physical work capacity. This is measured as the maximum resistance attained in watts when riding on a stationary bike during a specific time period (around 5 minutes). The measure is often denoted as Maximum Working Capacity (MWC) and has been found to be an important predictor of mortality among healthy men (e.g. Sandvik et al. 1993). Note that this measure is closely related to maximum oxygen uptake (VO2max), which has been labeled as the single best measure of cardiovascular capacity and maximal aerobic power (Hyde and Gengenbach 2007). ${ }^{11}$ A correlation of 0.9 between the two measures has been reported in the literature and it has therefore been concluded that MWC provides a suitable measure of aerobic capacity (Patton et al. 1982).

Since individual needs for energy vary with body size, maximum oxygen uptake is sometimes expressed relative to body weight. This is relevant for activities involving movement of the body such as walking or running, in which the body weight of the individual is not supported by an external source. In non-weight-bearing activities, such as swimming, cycling, and rowing, however, performance is less related to body weight (Wilmore and Costill 1994). In such activities, body weight therefore constitutes a negligible part of the resistance and performance is then usually expressed in absolute terms (Buckley et al. 1999; Heyward 2006). Since riding a stationary bike is indeed a

\footnotetext{
${ }^{11}$ Directly measuring maximum oxygen uptake is costly and time-consuming, meaning that indirect measures are often preferred when large numbers of people are being tested.
} 
non-weight-bearing activity, this is also the approach that we are taking in our analyses. ${ }^{12}$ As we will see in the results section, our measure of working capacity is also a significant and important predictor of earnings, suggesting that is indeed picks up something that is valued on the labor market. ${ }^{13}$

In our OLS regressions, we control for age fixed effects, which picks up any nonlinearity in the age profile for earnings but also any changes in the measurement of the enlistment variables from year to year. Since 99 percent of the conscripts enlisted at age 18 or 19 (86 and 13 percent, respectively) the age fixed effects also pick up anything specific for the year the conscript enlisted. It is therefore reassuring that the results are insensitive to how we handle the age and age-when-enlisting variables, that is, including additional controls for age (fixed effects) when enlisting, or only including a control for linear age, does not change the results at all.

Height is obviously not the only dimension of bodily size. There is a large body of research on the impact of being overweight or obese on labor market outcomes, reaching

\footnotetext{
${ }^{12}$ It should be mentioned that there is a small but significant negative correlation between MWC/kilogram and height, which means that the former cannot explain the height premium. This suggests that it is a person's uncorrected strength and power that explains the height premium.

${ }^{13}$ It is important that our measure of physical capacity is not mechanically related to height, i.e. being height biased such that tall people automatically achieve better scores. This is not the case, however, and some elementary insights from mechanics explain this. On the stationary bike test, the resistance is exerted from the center of the bottom bracket (on new ones by magnets and on old ones by a wheel) and is regulated by a shifter. The crank arms are of standard length and so is the speed at which the person is pedaling (60 rpm), by following a beat meter. Note also that the person must sit down when pedaling so that taller people could not exploit their greater weight when pushing down the pedals. Hence, the resistance measured in watts in the pedal stroke is by construction mechanically the same for everyone and irrespective of any personal characteristic. Maximum watts are then attained at by increasing the resistance to the threshold of the person's working capacity. Finally, the height of the saddle is adjusted to fit the individual's leg length to be straight when having the crank arm in a vertical position. Given this, there is no obvious way in which taller individuals would have an advantage in pressing down the pedal. If anything, since there is a limit to how far the saddle may be raised, taller individuals would be at a disadvantage since their knee angle would be non-optimal. To conclude, our stationary bike test is a measure of maximum watts attained that does not automatically favor tall people. Hence, the positive correlation between height and our measure of physical capacity reflects that taller people have greater physical capacity due to environmental and genetic factors.
} 
somewhat mixed results for males (see Lundborg et al. 2007 and Rooth, in press, for an overview). Most studies in this literature use body mass index (BMI), as an indicator of "appropriate/inappropriate" body weight for a given height. To control for this dimension of bodily constitution, we add BMI in our estimations.

It should be noted that almost all people that enlisted during our study period also completed military service. For the vast majority of the study sample, the enlistment test results did not affect the decision as to whether they will have to do military service or not. Instead, the tests merely influence the individual's placement in the army, meaning that poorer results will typically lead to a less qualified and meriting placement. From this respect the incentives to deliberately underperform on the tests are limited. We will however perform some sensitivity tests in order to examine the role of "enlistment fakers" for our results.

Our data also includes information on parental years of schooling and earnings in 1980. For about 12-13 percent of the sample, however, data is missing on these variables (see Table A2 in the appendix). Moreover, for some of the other explanatory variables, there is missing information for certain individuals. ${ }^{14}$ When there is missing information in a cell, we have used the variable mean and created an additional binary variable indicator taking on the value one when information is missing and being zero otherwise.

Before moving on to the empirical part of our work, we also need to address the age at which height is measured. Both Persico et al. (2004) and Case and Paxson (2008a) include height measures at different ages in their earnings regressions, but come to different conclusions as to which age-specific height is most important for adult earnings. From this perspective, a limitation of the present study is that it only captures height at age 18. However, it should be noted that the association between height at a very young age and adulthood is very strong. The correlation coefficient between height at a young age and in adulthood is of the order of 0.7 (Case and Paxson, 2008b). Moreover, as discussed by Case and Paxson (2008a), if the association between height and earnings only reflects unobserved factors related to labor market success, inclusion of these factors in the regression should cause the coefficient of height to approach zero. This will then be

\footnotetext{
${ }^{14}$ For BMI, physical capacity and non-cognitive skills less than 0.1 percent of the population has missing information. For height and cognitive skills no information is missing (by data design).
} 
the case irrespective of whether single or multiple measures of height are used. Since our goal is to try to "explain" the height premium, having only a single measure of height is less problematic in our case.

The distributions for our key variables (log) earnings and height (at age 18) for the total population are illustrated in Figure 3.1. The figure shows that earnings rise with height across the entire height distribution, with an average return to height of approximately 0.6 percent per centimeter. ${ }^{15}$ The figure also suggests that the earnings/height rise is rather uniformly distributed in the mid section of the height distribution, but varies somewhat in the tails. We will return to this issue in Section 4.2.3, where results from quantile regressions are presented.

*** Figure 4.1 about here ***

We next address the raw associations between our main explanatory variables and earnings. Figures 3.2-3.4a show that both cognitive and non-cognitive skills, as well as maximum work capacity, are positively associated with earnings. ${ }^{16}$ Approximately one standard deviation increase in either characteristic is associated with ten percent greater earnings. This holds throughout the distributions. Also, all three characteristics correlate positively with height, as shown in Figures 3.5-3.7a. Hence, physical capacity and both types of skills are associated with height and earnings in a bivariate analysis. In the empirical section, we will then try to disentangle the extent to which the height premium in earnings may be attributed to these different types of characteristics.

\section{*** Figure 3.2, 3.3 and 3.4a,b about here $* * *$ *** Figure 3.5, 3.6 and 3.7a,b about here ***}

Descriptive statistics of the key variables used in the empirical analysis, i.e. earnings, physical and psychological test scores, etc., are given in Table 3.1 for those below and

\footnotetext{
${ }^{15}$ This is true both unconditional and conditional on age; see Table 4.1 for the corresponding estimate conditional on age.

${ }^{16}$ No clear association is found for handgrip strength, see Figure 3.4b.
} 
above median height. The main picture that emerges is that there are differences between taller and shorter men in all dimensions, but that these differences in general are small.

*** Table 3.1 about here $* * *$

\section{Method}

In order to correctly identify a height premium, care must be taken in choosing which variables to include in the earnings equation. In an influential article, Neal and Johnson (1996) argue that only exogenous variables, i.e., variables determined before labor market entry, should be included in the model specification. Variables commonly used to control for worker productivity, such as occupation and post-secondary education, are in this respect likely to be endogenous. Case and Paxson (2008a) argue in a similar vein that controlling for such variables would hide part of the height premium if taller individuals sort themselves into certain educations or jobs. Our main empirical specifications will therefore not include controls for education, occupation, or marital status. Instead, we perform a separate analysis where we examine the extent to which the height premium works through sorting into occupations or educational tracks.

In the previous section, we introduced three sets of potentially important personal characteristics; cognitive skills, non-cognitive skills, and physical capacity. All these were measured before entering the labor market, when enlisting for the military at age 18 , yielding two composite skill variables and two distinct variables capturing physical capacity (maximum work capacity and physical strength). By including them one by one, as well as all together, in the earnings equation, we will analyze to what extent they explain the crude height premium. Equation 1 shows the model used for the total population data using ordinary least squares:

1) $\quad$ Log Earnings $_{i}=a+b *$ Height $_{i}+c^{*} X_{i}+d^{*} F_{i}+e_{i}$,

where $i$ is index for individual, Height is a measure of individual height in centimeters, $X$ is a vector of individual characteristics measured when enlisting, and $F$ a vector of the parental characteristics. The model is then altered by including different variables into $X$. 
Our second specification in addition controls for unobserved family and parental characteristics by estimating a sibling fixed effect model:

2) $\quad$ Log Earnings Eij $=a+b *$ Height $_{i j}+c^{*} X_{i j}+f_{j}+e_{i j}$

where $f_{j}$ now represents family fixed effects capturing family characteristics common to all siblings within the same family. Identification of the coefficient $b$ thus relies upon sibling variation in height at age 18. In this specification, our estimate of $b$ should not be subject to bias due to any confounding influence from unobserved family-level unobservables that are also associated with earnings.

\section{Results}

\subsection{Explaining the height premium}

\subsubsection{Results for the total population data}

We start out with the full set of 448,702 observations, including only height and age into the earnings regression. As shown in Model A in Table 4.1, a ten centimeter increase in height is associated with six percent higher earnings. ${ }^{17}$ Interestingly, this height premium is only slightly reduced - by about one sixth (to 5.2 percent) - when parental characteristics are included, as shown in Model B. Model C then adds BMI, which, although being statistically significant and negatively associated with earnings, leaves the height premium unaltered. Hence, the hypothesis that the height premium in earnings reflects body mass rather than height can be ruled out. Models D to I then add the personal character traits one by one and in various combinations. The row denoted "Reduction (\%) in original (Model C) height premium" contains information about how much the estimated height premium is decreased in each Model D through I in comparison with Model C.

\footnotetext{
${ }^{17}$ In Section 4.2.4 we show that the height premium is non-linear, i.e., concave. Hence, this suggests the inclusion of height squared in the model being estimated in Table 4.1 and 4.2. However, since we are able to fully explain the height premium, we instead decided to follow the empirical specification used in Persico et al. (2004) and Case and Paxson (2008a) to facilitate the comparison of results.
} 
Starting with cognitive ability, the results from Model D clearly show that this is an important determinant of earnings since a one standard deviation increase in cognitive ability is associated with 11 percent higher earnings. Controlling for cognitive skill lowers the height premium by about one third to 3.6 percent, although still being statistically significant. Next, we consider non-cognitive skills (Model E). The findings suggest that such skills are of roughly equal importance as cognitive skills, since a one standard deviation increase in the non-cognitive score increases earnings by 13 percent. Controlling for non-cognitive skills reduces the premium by slightly more than one third to 3.3 percent. Taken together (results not shown), i.e., including the cognitive and noncognitive skill measures simultaneously, reduces the height premium by half to 2.6 percent.

Next, we add our measures of physical capacity. Clearly, physical capacity in the form of maximum work capacity (MWC) (Model F) is positively associated with earnings; a one standard deviation increase in the MWC is associated with an 8 percent increase in earnings. This is an interesting finding in itself and note that this estimate is not confounded by height or BMI, which are controlled for in the regressions. Incorporating physical capacity into the earnings equation also reduces the original height premium by almost two thirds to 1.8 percent. Our other measure of physical capacity -handgrip strength -- is less associated with both earnings and the height premium (Model G), but its impact on the latter matches the corresponding impacts of cognitive and noncognitive skill, as it reduces the premium by about one third to 3.5 percent. Taken together (Model H), i.e., including muscular strength and MWC simultaneously, reduces the original height premium by 81 percent to 1.0 percent. This suggests that physical capacity explain the height premium in earnings to a greater extent than both cognitive and non-cognitive skills.

Finally, by comparing the parameter estimates when including all measured character traits simultaneously (Model I) it is evident that skills are more closely related to earnings than physical capacity. However, compared with Model H, adding cognitive and noncognitive skills to the earnings equation does not further reduce the estimated height 
premium. In this final model, we still obtain a small but statistically significant height premium of 1.3 percent.

\subsubsection{Results for siblings}

The results presented above may be biased if there are important unobserved family-level characteristics that are associated with both earnings and our various measures of personal characteristics. Moreover it is possible that some of the personal characteristics are more associated with family background than others. In order to control for any such family-specific unobservable factors, we next re-estimate the models in the previous section on the 145,210 brothers in the sample. The results are shown in Table 4.2.

First of all, regressing earnings on height and age without sibling fixed effects yields a height premium for the sibling sample that exactly corresponds to the result for the total population data, (Model A). The height premium is lowered from 6.2 to 4.2 percent when introducing sibling fixed effects (Model A and B), suggesting that factors operating at the family-level explain a third of the crude height premium. Adding BMI (Model C) again leaves the height premium unaltered. Cognitive (Model D) and non-cognitive (Model E) skills are similarly associated with earnings as well as the height premium; an increase of one standard deviation in each being associated with a 10 and 9 percent change in earnings, respectively, with the original height premium (from Model C) being lowered by about 30 percent. Including both cognitive and non-cognitive skills lowers the height premium by slightly less than half (to 2.2 percent, not shown in Table 4.2).

*** Table $4.2 * * *$

Turning to physical capacity, although less associated with earnings than skills, both maximum work capacity (Model F) and strength (Model G) strongly affect the height premium, reducing the premium by 50 and 38 percent, respectively. Including both physical capacity variables lowers the height premium by 74 percent, from 4.2 to 1.1 percent (Model H). Adding cognitive and non-cognitive skills to this model essentially explains the entire height premium (Model I); the remaining height premium is now 0.8 percent and is statistically insignificant. 


\subsubsection{Leadership skills}

We next take advantage of the fact that we have a more specific measure of noncognitive skills for part of the sample; leadership skills. This may capture elements of non-cognitive skills that are more directly related to height, as would be suggested from the theory of interpersonal dominance, for instance. We therefore re-estimate the models using the part of the siblings data where we have information on leadership skills, i.e., for those who scored a five or above on the cognitive test score. ${ }^{18}$ About one third of the sibling sample is excluded by this restriction. This exercise serves both as a complement to the previous analysis as well as a sensitivity check for (1) using an alternative measure of non-cognitive skill and (2) excluding enlistees with comparably low cognitive test scores. The results are shown in Table 4.3.

**** Table $4.3 * * *$

Overall, the results for this restricted sample follow the results from Model C in Table 4.2 rather well with a height premium of 4.0 instead of 4.2 percent. Cognitive skills lower the height premium by 22 percent (Model B), physical capacity by 80 percent (Model C), and adding all these variables to the earnings equation makes the height premium disappear (Model D). Including leadership skills decreases the height premium from Model A by 35 percent (Model E), while including cognitive skills and leadership skills simultaneously explains almost half of the height premium (Model F). When adding all personal character traits at once to the earnings equation more than 90 percent of the height premium is explained (Model I). In all, restricting the sample to those scoring 5 or above on the cognitive test and employing leadership skills instead of the broader noncognitive skill measure does not affect the results to any important extent.

\footnotetext{
${ }^{18}$ However, there are 308 men $(0,3 \%)$ who scored below five that were still evaluated. These cases are included in the analysis since their inclusion did not affect the results.
} 


\subsection{Sensitivity analysis}

\subsubsection{Sorting by height into regions, occupations and educations}

As discussed above, endogenous variables such as education and occupational choice should not be included in the regressions in Section 4.1. Doing so would underestimate the height premium, if part of it works through these endogenous variables. In this section, however, we are interested in whether tall and short males in fact do sort themselves into different geographical locations, certain occupations, or levels of education. For this purpose, we construct indicators of residence, occupation, and education. Since Sweden is divided into 22 counties, we first constructed 22 dummies indicating geographic location. Second, we categorize the variable measuring occupation into 115 different occupational groups according to SSYK (Standard for Swedish Occupational Classification), a three digit occupational classification code similar to the international classification (ISCO). Third, schooling categories are constructed from the Swedish version of the educational attainment variable ISCED97 and is distributed between nine to twenty years of schooling. These indicators are then entered as fixed effects in the regressions.

\section{*** Table $4.4 * * *$}

As shown in Table 4.4, there are no indications that taller individuals sort themselves into specific regions, since the height premium is more or less unaffected when including region fixed effects (see Model A and B of Table 4.4). On the other hand, there is quite a strong sorting into occupations, such that taller individuals sort themselves into higher paying occupations. The within occupation height premium is on average less than half of the unconditional height premium (see Model A and C). The sorting is less pronounced when it comes to education, as the crude height premium is reduced by about one third when controlling for schooling fixed effects (see Model A and D). ${ }^{19}$ Finally, including all three variables (Model E) reduces the height premium by 58 percent which rather closely mirrors the reduction (55 percent) obtained by controlling for occupation only (Model C).

\footnotetext{
${ }^{19}$ These results are similar when using the sibling sample, see Table A4 in appendix.
} 


\subsubsection{Sensitivity of the earnings measure}

In this section, we elaborate with our earnings measure to infer whether the results are sensitive to extreme earnings, low earnings (below a 100' SEK), exclusion of sickness benefits, and when excluding potential enlistment "fakers". In this analysis, the sibling sample is used and a comparison is made to the height premium estimates of Models B, $\mathrm{C}, \mathrm{D}, \mathrm{H}$ in Table 4.2. The results are presented in Table 4.5.

\section{*** Table $4.5 * * *$}

\section{Top coded earnings}

In the first column (i) of Table 4.5, the estimates from Table 4.2 are replicated whilst in the second column (ii) the corresponding estimates are found when top coding high earnings to 500' SEK. The results indicate that extreme earnings of taller males are not driving the results of Section 4.1. ${ }^{20}$

\section{Hourly wage or hours worked?}

Annual earnings are the product of weeks worked during the year, hours worked per week, and the hourly wage. Since higher earnings are more likely to be based on similar amounts of time worked (hours and weeks), using a threshold for earnings should give a height premium that comes closer to the one expected for (log) hourly wages (if such data was available). Antelius and Björklund (2000) show, for Swedish circumstances, that if a threshold of 100,000 SEK (approximately 10,000 euro) is used when analyzing annual earnings based on tax records, one receives a return to education similar to the one obtained from analyzing hourly wages.

If this result can be extrapolated to the earnings measure in this study, estimating the height premium for those earning above 100,000 SEK should give us a height premium that should reflect the premium one would obtain if using the hourly wage rate. Hence, we conduct a sensitivity analysis using an earnings threshold of 100,000 SEK. When excluding those with earnings below 100,000 SEK, we only lose 12,313 individuals, or 8 percent, of the sample, see column (iii) of Table 4.5. The crude height premium is

\footnotetext{
${ }^{20}$ A total of 4,163 individuals had earnings above 500' SEK.
} 
reduced by twenty-four percent for this restricted sample, from 0.042 to $0.032 .^{21}$ This confirms that the main part of the height premium reflects that taller individuals have higher hourly wages but it also indicates that a smaller part of the height premium in earnings (about a quarter in this exercise) may be attributed to taller individuals working more hours. The result is also consistent with a greater height premium for those earning less than 100,000 SEK, an issue we explore in greater detail in Section 4.2.3.

\section{Only labor income and self-employment earnings}

As discussed in Section 2, an individual's final adult height might be correlated with his health through early life developmental processes. Hence, height differentials in earnings may capture differences in health status not captured by our measures of physical capacity and this may then show up in that unhealthier (shorter) individuals are on sickness benefits more often. In the analyses in Section 4.1 and 4.2, we therefore use an earnings measure including sickness benefits. In order the check the sensitivity of our results to the inclusion of sickness benefits, we re-run our regressions with an measure of earnings that only include labor income and/or self employed income. Here, we had to exclude a smaller fraction of the population, 1,686 individuals, since their earnings only consisted of sickness benefits. As shown in column (iv) of Table 4.5, the results are virtually unaltered when compared to column (i) and hence, not sensitive to the choice of including or excluding sickness benefits in our measure of earnings.

\section{Enlistment "fakers"}

Some individuals may deliberately underperform on the enlistment test in order to avoid certain positions in the military. For instance, those scoring above average on the cognitive test were evaluated on leadership skills and therefore ran the risk of serving more months in a leadership position, although with a higher rank. Hence, to escape serving more months, a successful strategy would be to score low on the cognitive test. Although we find this somewhat unlikely, we excluded everyone scoring a 1 or a 2 on the cognitive test and re-ran our analysis, thereby excluding 14,151 individuals, or ten

\footnotetext{
${ }^{21}$ That it becomes smaller is not surprising, given that the height premium is greater at low percentiles of the earnings distribution compared to at the median, see Section 4.2.3.
} 
percent of the original sample. The results in column (v) are basically unaltered when compared to column (i). Summarizing this section, our sensitivity analyses show that the results of Section 4.1 are quite robust.

\subsubsection{The height premium at different parts of the earnings distribution}

Figure 3.1 suggested that the height premium, though rather uniformly distributed through the main part of the height distribution, varied somewhat along its tails. In Section 2, we also discussed that the height premium may reflect skills and physical capacity to a varying extent depending on the point at which the height premium is evaluated within the earnings distribution. To analyze this issue more thoroughly, we run quantile regressions on earnings using two different models. In the first model (Model A) only height and age are included as controls, while in the latter (Model B), we use the full set of variables (corresponding to Model I in Table 4.1). The results are shown in Table 4.6.

\section{**** Table 4.6 and Figure 4.1***}

For Model $\mathrm{A}$, we find that the height premium at the $10^{\text {th }}$ and $90^{\text {th }}$ earnings percentile is 8 and 7 percent, respectively, while the median return is 4 percent. Hence, the further away from median earnings, the greater is the return to an additional centimeter in height. Still, our extensive set of control variables explains the lion's share of the crude height premium at all percentiles (Model B). This is further illustrated in Figure 4.1 where the estimated height premiums of Models A and B from Table 4.6 are plotted. It should be noted though that there is a tendency that skills and physical capacity explain more of the height premium at the lower end of the earnings distribution. At the lower, the height premium is actually fully explained, whereas a significant height premium remains at the upper end. Most likely, this reflects the fact that physical capacity is a more important trait at the lower part of the earnings distribution, where jobs are more likely to involve physical labor. This is confirmed in the third column of Table 4.6 and in Figure 4.1, which gives the height premium at different percentiles when only height, BMI, parental characteristics and physical capacity are added to the earnings equation (Model C). In 
fact, the remaining height premium even becomes negative at the $5^{\text {th }}$ and $10^{\text {th }}$ percentile, while the results for the other percentiles closely correspond to the results from Model B.

\subsubsection{The height premium at different heights.}

In this section, we analyze whether the height premium varies by height. For this purpose, we divide the sample into three groups as follows: below 175 centimeters, 175185 centimeters, and above 185 centimeters. ${ }^{22}$ Table 4.7 gives the results for the total sample and for the sibling sample. For the full sample, it is evident that the height premium is inversely related to height. For all models (Models B through I), the height premium is statistically significant among the shorter individuals, whereas it is virtually non-existent for those above $185 \mathrm{~cm} .^{23}$ Thus, the height premium is largely found among individuals below average height. ${ }^{24}$

\section{*** Table $4.7 * * *$}

\section{Discussion}

We find that an additional ten centimeters in height, which is approximately four inches $^{25}$, is associated with a raw height premium of six percent. This is somewhat lower than the ten percent height premium in wages found by Persico et al. (2004) and Case and Paxson (2008a), but could probably be explained by the institutional setting in Sweden,

\footnotetext{
${ }^{22}$ We have also elaborated by trimming the ends of the height distribution, i.e. ascribing a height of 165 and 195 centimeters to those below and above that height, respectively. Moreover, we ran analyses discarding those with height below or above 165 and 195 centimeters, respectively, resulting in a loss of 2,517 individuals. These restrictions did not change the results of Table 4.1 or 4.2 and are available upon request.

${ }^{23}$ Since most of the estimates for the sibling sample are statistically insignificant, these are not commented upon.

${ }^{24}$ The height premium may also vary by age. We tested this by interacting age with height, without finding any clear patterns. We also ran regressions discarding younger men, aged 28-32, from the population, which did not change the results. These results are available upon request from the authors.

${ }^{25}$ Corresponding to the inter quartile difference in height in the UK, US, and Sweden.
} 
with the existence of "solidarity" wages and a rather narrow wage distribution. ${ }^{26}$ It could be noted that the height premium in the three countries corresponds to the return to one additional year of schooling in the respective countries - about ten percent in the US and UK (Card, 1999) and six percent in Sweden (using the data explored in this study). Hence, the earnings height premium for Sweden, though somewhat lower than the wage premiums in US and UK, is still substantial. ${ }^{27}$

We replicate the findings in Persico et al. (2004) and Case and Paxson (2008a), i.e. that both cognitive and non-cognitive skills are responsible for explaining part of the height premium. We then introduce a third individual characteristic - physical capacity that explains an even greater part of the height premium. It has previously been assumed that whereas physical capacity may account for important parts of the height premium in developing countries, where muscular strength and physical capacity are of importance in the production process, it is of limited importance in explaining the height premium in modern western societies. Our results stand in sharp contrast to this assumption. In fact, we find that measures of physical capacity alone accounts for about 80 percent of the height premium. We also find a significant and positive association between physical capacity and earnings, which is independent of height and BMI. A one standard deviation increase in the MWC is associated with an 8 percent increase in earnings, suggesting that physical capacity is indeed something that is valued in the labor market. By also accounting for cognitive and non-cognitive skills in our regressions, we are able to explain the entire height premium in earnings.

Speculating, we propose some potential pathways by which physical capacity may be linked to the height premium. Firstly, and as discussed in Section 2, measures of physical capacity, such as muscle strength, have been found to predict lower total mortality and mortality from cancer and respiratory diseases. Physical capacity and strength therefore

\footnotetext{
${ }^{26}$ Sweden has a much more compressed wage structure than the US. In Sweden, the $90^{\text {th }}$ percentile earns approximately twice as much as the $10^{\text {th }}$ percentile, whereas in the US they earn five times as much.

${ }^{27}$ Its magnitude could also be related to the ethnic and immigrant earnings gaps in Sweden. The annual earnings of men born in Sweden with a non-European parental background is sixteen percent lower compared to the earnings of native Swedish men (Nordin and Rooth, in press), which, based on the raw results of this study, is equivalent to the difference in earnings between men that differ by about twentyseven centimeters in height. The observed Swedish gender earnings gap is 16 percent (Kumlin 2007).
} 
signal good health (Metter et al. 2002; Gale et al. 2007; Wijndaele et al. 2007). Due to the strong correlation between height and physical capacity, employers may therefore use height as a marker of long-term health, which is rewarded in the labour market. Secondly, technological advancements have not completely removed physically demanding jobs in western countries. In line with this, our results suggest that the height premium to a larger extent reflects physical capacity at the lower end of the earnings distribution, where jobs can reasonably be assumed to be more physically demanding and where physical capacity is thus more directly related to the productivity of the individual. Thirdly, insofar physical capacity is associated with habits such as exercise and a balanced diet it may, apart from health, signal certain rewarded personality traits, such as self-control, endurance and patience, etc., i.e. traits that partly coincide with the notion of noncognitive skills. Finally, physical strength has been related to attractiveness. This would mean that the physical strength that comes with greater height is mainly rewarded because physical strength is perceived as attractive. An interesting route for future research would be to distinguish between these alternative explanations and further explore alternative mechanisms by which physical capacity is linked to the height premium. 


\section{References:}

Antelius, J. and Björklund, A. (2000). How Reliable are Register Data for Studies of the Return on Schooling? An examination of Swedish Data, Scandinavian Journal of Educational Research, 44(4):341-355.

Behrman, J.R. and Rosenzweig, M.R. (2004). Returns to birthweight, Review of Economics and Statistics, 86(2):586-601.

Black, S.E., Devereux, P.J. and Salvanes, K.G. (2007). From the cradle to the labor market? The effect of birth weight on adult outcomes, Quarterly Journal of Economics, 122(1): 409-439.

Blair, S.N., Kohl, H.W. III, Paffenbarger, R.S. Jr., Clark, D.G., Cooper, G.H., and

Gibbons, L.W. (1989). Physical fitness and all-cause mortality: a prospective study of healthy men and women. JAMA 262:2395-2401.

Borghans, L., Duckworth, A., Heckman J., and ter Weel B. (2008). The Economics and Psychology of Personality Traits, Journal of Human Resources, 43(4): 972-1059.

Buckley, J., Holmes, J., and Mapp, G. (1999). Exercise on prescription. Cardiovascular activity for health. Butterworth-Heinemann; 1 edition.

Card, D. (1999). The Return to Education. In Ashenfelter O, Card D (eds) Handbook of Labor Economics, pp. 1801-1863. Elsevier. Amsterdam.

Carroll, J. (1993). Human cognitive abilities. A survey of factor-analytic studies, Cambridge: University Press.

Case, A. and Paxson, C. (2008a). Stature and status: Height, ability, and labor market outcomes, Journal of Political Economy, 116(3):499-532. 
Case, A. and Paxson, C. (2008b). Height, Health and Cognitive Function at Older Ages, American Economic Review: Papers and Proceedings, 98 (2): 463-467.

Cawley, J., Heckman, J. and Vytlacil, E. (2001). Three observations on wages and measured cognitive ability, Labour Economics, 8(4):419-442.

Dinda, S., Gangopadhyay, P.K., Chattopadhyay, B.P., Saiyed, H.N., Pal, M. and Bharati, P. (2006). Height, weight and earnings among coalminers in India, Economics and Human Biology, 4(3):342-350.

Ekelund, L-G., Haskell, W.L., Johnson, J.L., Whaley, F.S., Criqui, M.H., and Sheps, D.S. (1988). Physical fitness as a predictor of cardiovascular mortality in asymptomatic North American men: the Lipid Research Clinics Mortality Followup Study. New England Journal of Medicine, 319:1379-1384.

Everett P. and Sills F. (1952). Relationship of grip strength to stature, somato-type components and anthropometric measurements of hand, Res $Q, 23: 161-6$.

Fink, B., Neave, N. and Seydel, H. (2007). Male facial appearance signals physical strenght to women, American Journal of Human Biology, 19:82-87.

Frieze, I.H., Olson, J.E., and Good, D.C. (1990). Perceived and Actual Discrimination in the Salaries of Male and Female Managers, J. Appl. Soc. Psychology, 20: 46-67.

Fujita, Y., Nakamura, Y., Hiraoka, J., Kobayashi, K., Sakata, K., Nagai, M., and Yanagawa, H. (1995). Physical-strength tests and mortality among visitors to healthpromotion centers in Japan. J Clin Epidemiol, 48:1349-59.

Gale, C.R., Martyn, C.N., Cooper, C., and Sayer, A.A. (2007). Grip strength, body composition, and mortality. Int J Epidemiol, 36:228-35. 
Gale, C.R., Martyn, C.N., Kellingray, S., Eastell, R., Cooper, Cyrus. (2001). Intrauterine programming of adult body composition, J Clin Endocrinol Metab, 86:267-72.

Gallup AC, DD White, GG Gallup Jr (2007). Handgrip strength predicts sexual behavior, body morphology, and aggression in male college students. Evolution and Human Behavior, 28:423-429.

Hamermesh, D. and Biddle, J. (1994). Beauty and the labor market, American Economic Review, 84:1174-1194.

Harper, B. (2000). Beauty, Stature and the Labour Market: A Brittish Cohort Study, Oxford Bulletin of Economics and Statistics, 62(1):771-800.

Heckman, J. (2008). Schools, Skills and Synapses, Economic Inquiry, 46(3): 289-324, 2008.

Heckman, J., and Rubinstein, Y. (2001). Importance of Noncognitive Skills: Lessons from the GED Testing Program, American Economic Review, 91(2):145-149.

Heckman, J.J., Stixrud, J. and Urzua, S. (2006). The effects of cognitive and noncognitive abilities on labor market outcomes and social behavior, Journal of Labor Economics, 24(3):411-482.

Heyward, Vivian H. (2006). Advanced Fitness Assessment and Exercise Prescription. Human Kinetics Publishers

Hyde, Thomas E. and Marianne S. Gengenbach (2007). Conservative Management of Sports Injuries. 2nd ed; Sudbury, Mass.: Jones \& Bartlett, p 845.

Kahn, H.S., Narayan, K.M., Williamson, D.F., and Valdez, R. (2000). Relation of birth weight to lean and fat thigh tissue in young men, Int J Obes Relat Metab Disord, 24:667-72. 
Komlos, J. (1990). Height and Social Status in Eighteenth-Century Germany. Journal of Interdisciplinary History (20): 607-621. 1990.

Kumlin, J. (2007). The Sex Wage Gap in Japan and Sweden: The Role of Human Capital, Workplace Sex Composition, and Family Responsibility, European Sociological Review, 23(2):203-221.

Loh, E. (1993). The Economic Effects of Physical Appearance, Social Science Quarterly, 74(2):420-438.

Lundborg, P., Bolin, K., Höjgård, S. and Lindgren, B. (2007). Obesity and Occupation Attainment among the 50+ of Europe, in Bolin, K. and Cawley, J. (Eds.), Advances in Health Economics and Health Services Research, Vol.17, The Economics of Obesity. Elsevier, New York, 219-252

Metter, E.J., Talbot, L.A., Schrager, M., and Conwit. R. (2002). Skeletal muscle strength as a predictor of all-cause mortality in healthy men, J Gerontol A, 57:B359-B365.

Neal, D. and Johnson, W. (1996). The Role of Premarket Factors in Black-White Wage Differences, Journal of Political Economy, 104 (4): 869-895.

Nordin, M. and Rooth, D. (in press). The Employment and Income Gap Between Natives and Second-Generation Immigrants in Sweden, Scandinavian Journal of Economics.

Patton, J.F., Vogel, J.A., Mello, R.P. (1982). Evaluation of a maximal predictive cycle ergometer test of aerobic power. European journal of applied physiology and occupational physiology, 49(1):131-40. 
Persico, N., Postlewaite, A, and Silverman, D. (2004). The Effect of Adolescent Experience on Labor Market Outcomes: The Case of Height, Journal of Political Economy, 112(5):1019-1053.

Phillips, D.I.W. (1995). Relation of fetal growth to adult muscle mass and glucose tolerance. Diabet Med, 12:686-90.

Richards, M., Hardy, R., Kuh, D. and Wadsworth, M.E.J. (2002). Birthweight, postnatal growth and cognitive function in a national UK birth cohort, International Journal of Epidemiology, 31(2):342-348.

Rooth, D. (in press). Obesity, attractiveness and differential treatment in hiring - a field experiment. Journal of Human Resources.

Sandvik, L., Erikssen, J., Thaulow, E., Erikssen, G., Mundal, R., and Rodahl, K. (1993). Physical fitness as a predictor of mortality among healthy, middle-aged Norwegian men. N Engl J Med, 328: 533-537

Silventoinen, K., Magnusson, P., Tynelius, P., Kaprio, J., and Finn Rasmussen. (2008). Heritability of body size and muscle strength in young adulthood: a study of one million Swedish men, Genetic Epidemiology, 32:341-349.

Slattery, M.L., Jacobs, D.R.Jr. (1988). Physical fitness and cardiovascular disease mortality: the US Railroad Study. American Journal of Epidemiology 127:571580.

Steckel, R.H. (1995). Height and the standard of living, Journal of Economic Literature 33:1903-1940.

Steckel, R.H. (2009). Heights and human welfare: Recent developments and new directions, Explorations in Economic History, 46 (1): 1-23. 
Thomas, D., and Strauss, J. (1997). Health and wages: Evidence on men and women in urban Brazil, Journal of Econometrics, 77(1):159-185.

van den Berg, G., Lundborg, P., Nystedt, P., Rooth, DO. (2009). Critical Periods During Childhood and Adolescence: A Study of Adult Height Among Immigrant Siblings. IZA DP no. 4140.

Wijndaele, K., Duvigneaud, N., Matton, L., Duquet, W., Thomis, M., Beunen, G., Lefevre, J., and Philippaerts, R.M. (2007). Muscular strength, aerobic fitness, and metabolic syndrome risk in Flemish adults, Med Sci Sports Exerc 39:233-240.

Wilmore, J.H., and Costill, D.L. (1994). Physiology of Sport and Exercise. Human Kinetics: Champaign. 


\section{Figures:}

Figure 3.1. Logarithm of annual earnings and height. Total population, 28-38 years old in 2003.

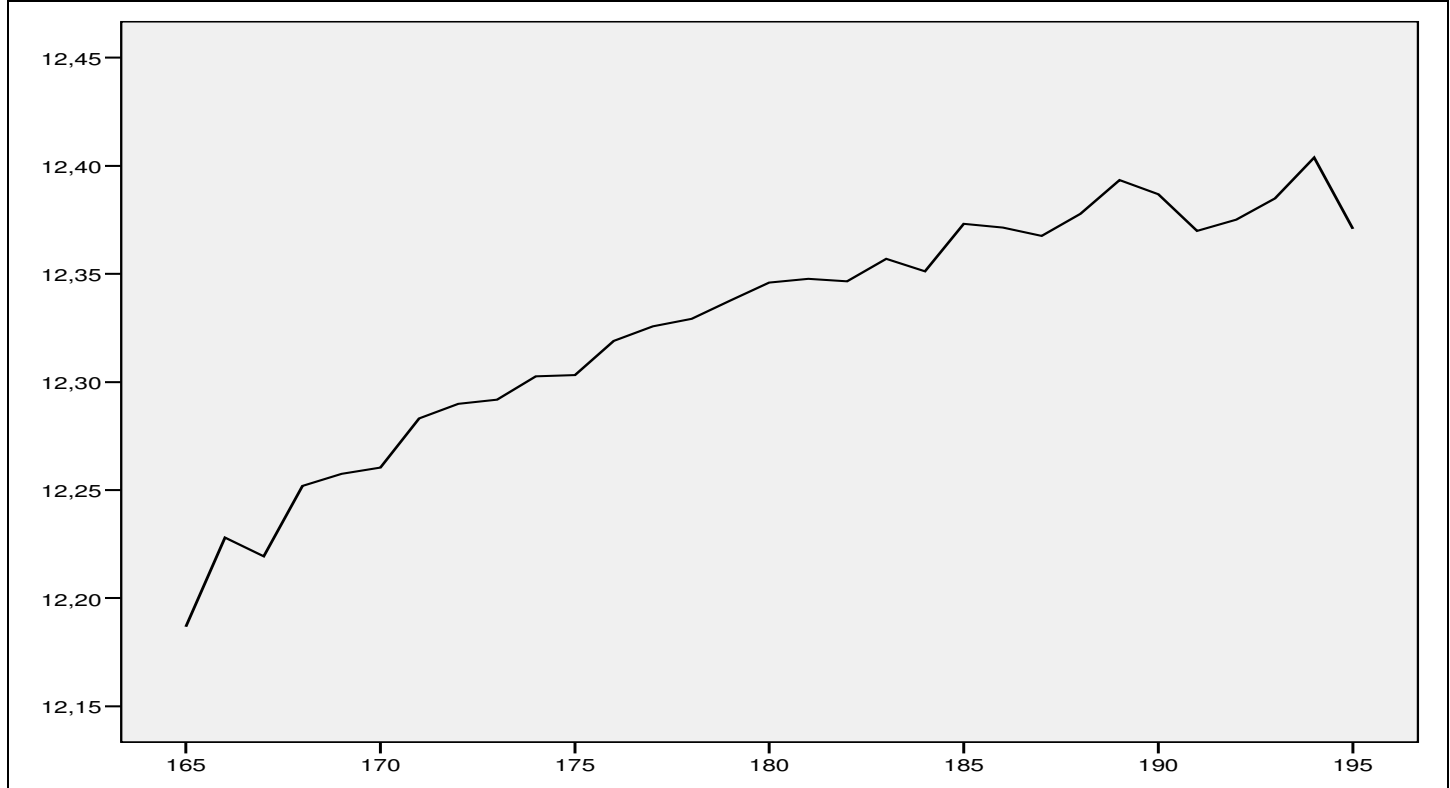

Note: The Height variable has been trimmed at the 1st and 99th percentile, that is, at 165 and 195 centimeters. The graph shows average earnings for each centimeter in height.

Figure 3.2. Logarithm annual earnings and cognitive skills. Total population, 28-38 years old in 2003.

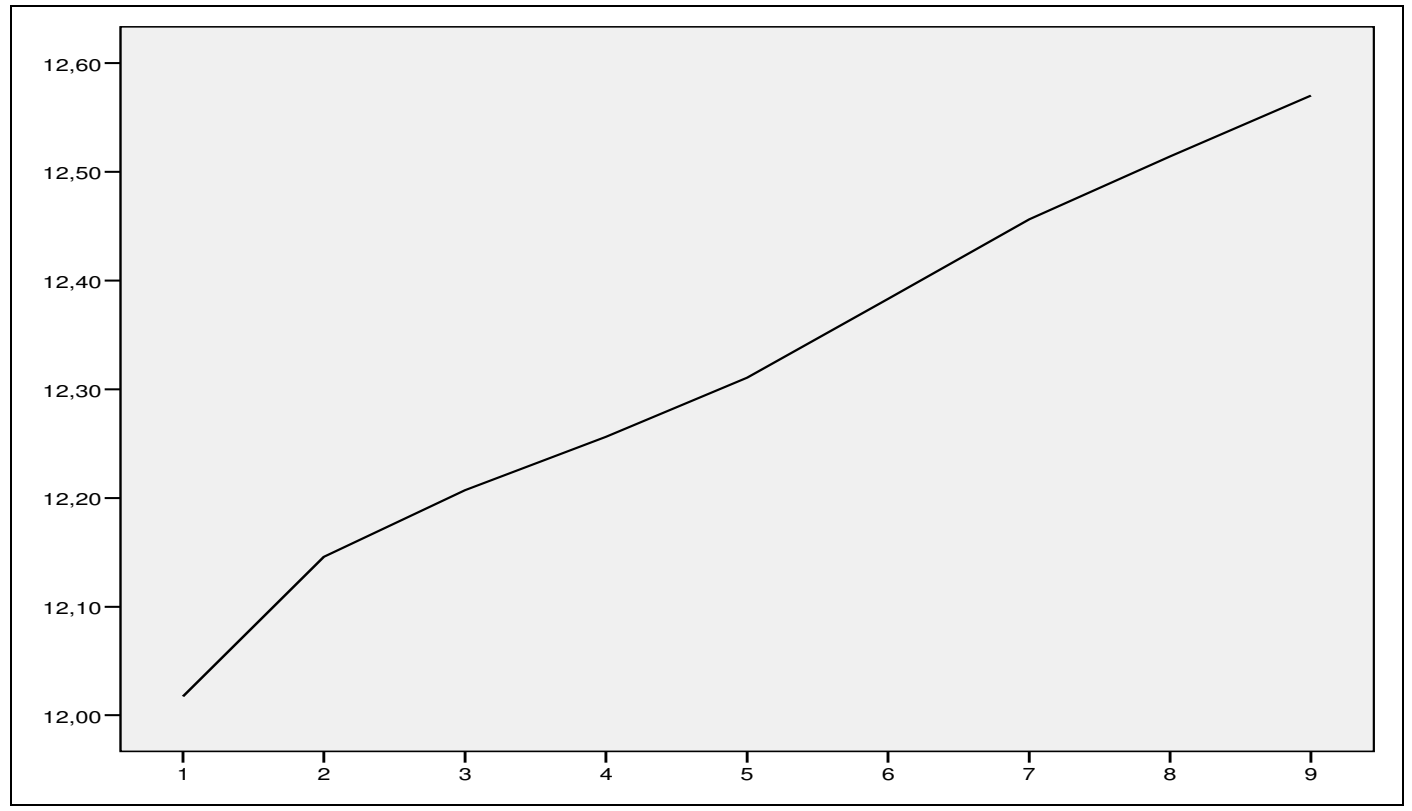

Note: One standard deviation in the cognitive skills variable is approximately 2 units and amounts to about ten percent higher earnings. Cognitive skill is the Enlistment Test Score on cognitive ability. The graph shows average earnings for every integer of the cognitive test score. 
Figure 3.3. Non-cognitive skill and earnings.

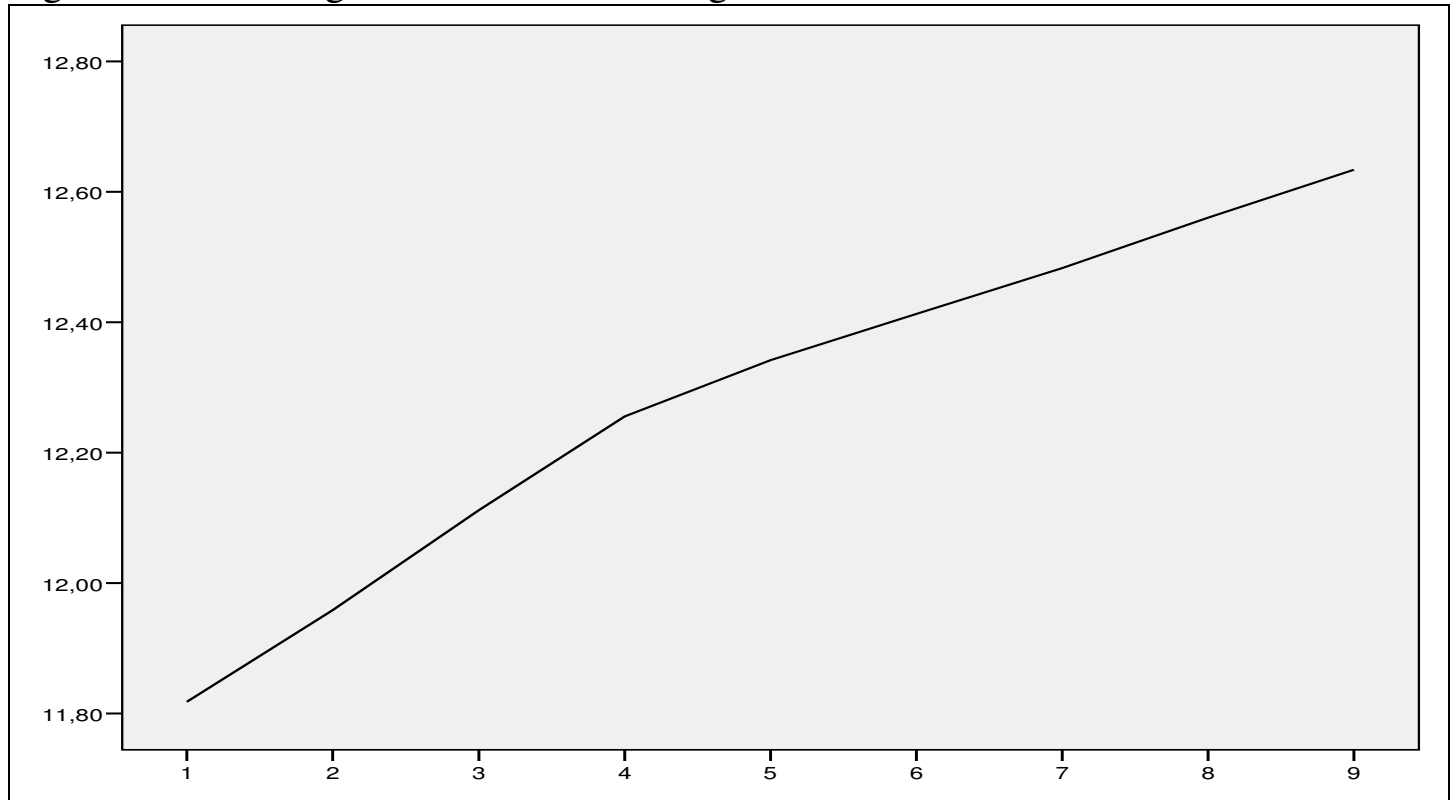

Note: One standard deviation in the non-cognitive skill variable is approximately 2 units and amounts to about ten percent higher earnings. Non-cognitive skill is the psychological evaluation when enlisting. The graph shows average earnings for every integer of the non-cognitive measure.

Figure 3.4a. Physical capacity (Maximum work capacity) and earnings.

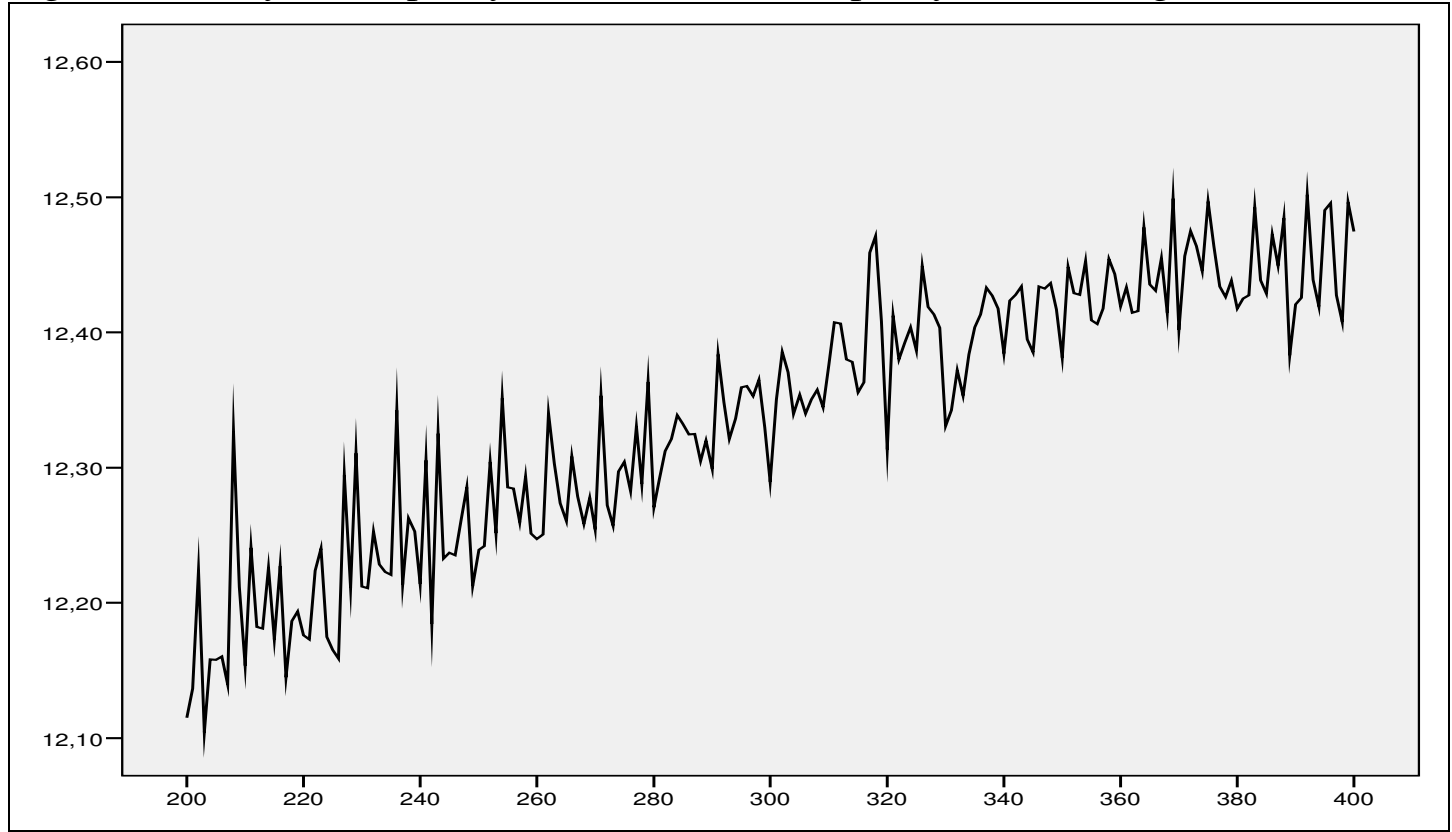

Note: One standard deviation in maximum work capacity is 50 units and amounts to about ten percent higher earnings. Maximum work capacity is taken from the Enlistment stationary bike test. The graph shows average earnings for every integer of the bike test score. 
Figure 3.4b. Physical capacity (handgrip strength) and earnings.

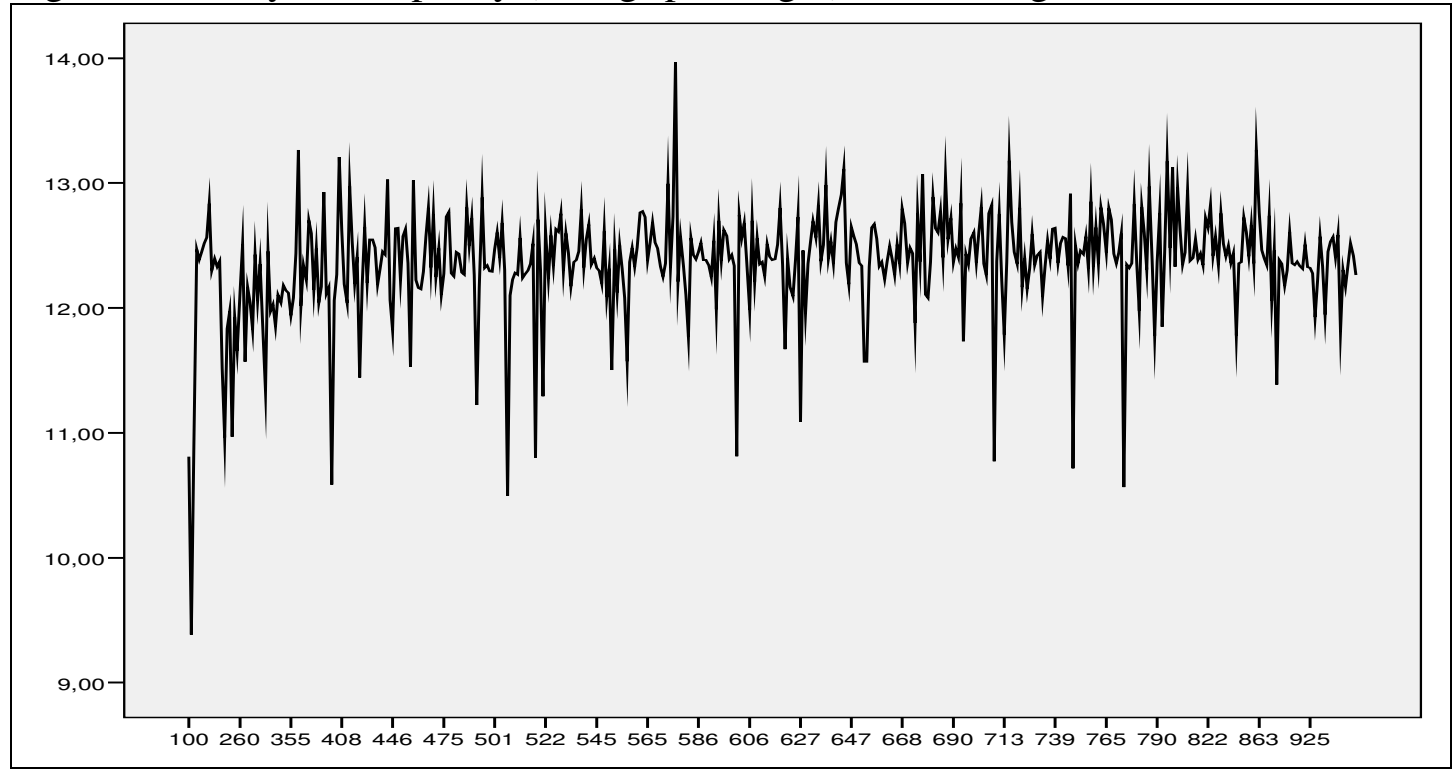

Note: One standard deviation in handgrip strength is 100 units. The graph shows average earnings for every integer of the handgrip strength score.

Figure 3.5. Cognitive skill and height.

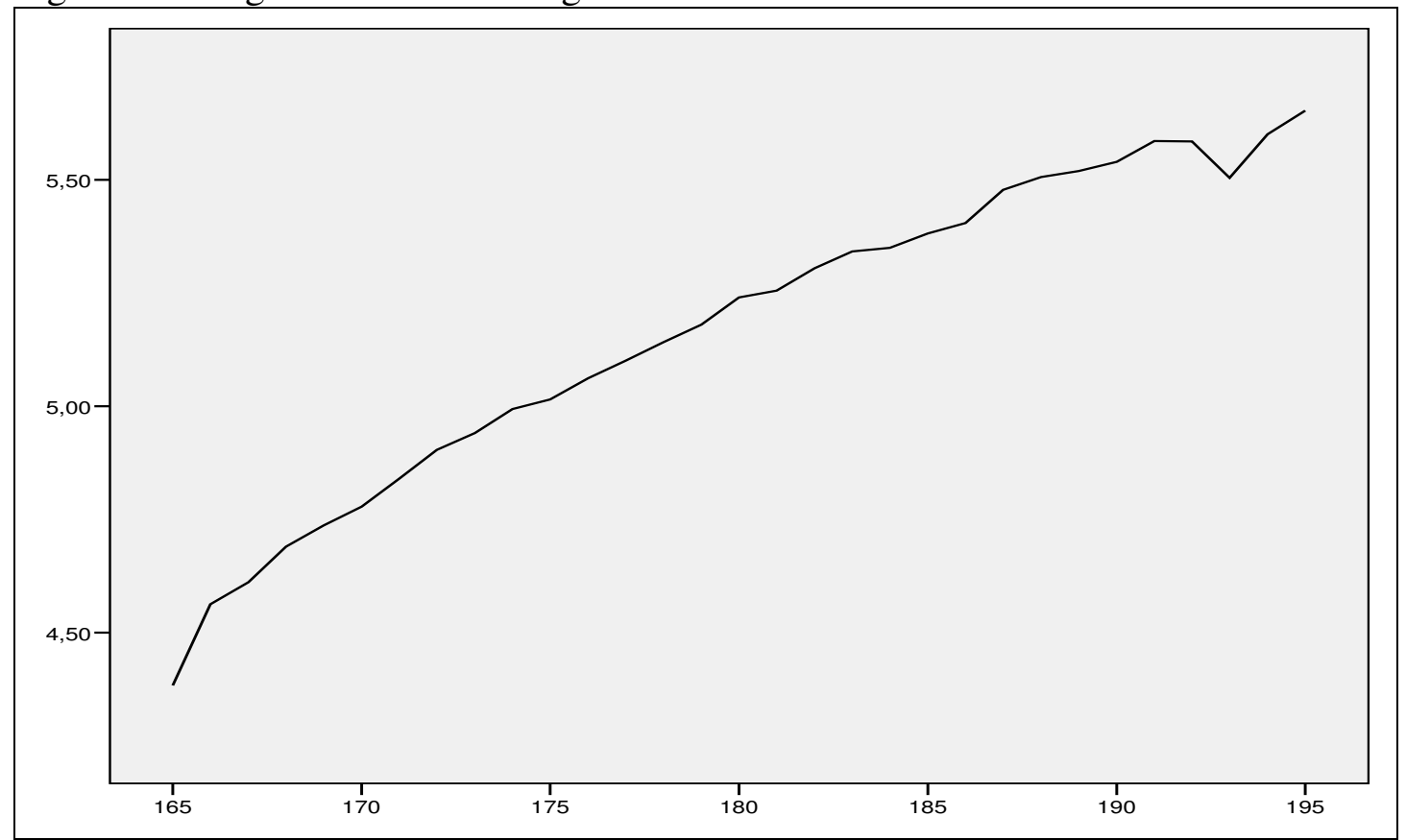

Note: The Height variable has been trimmed at the 1st and 99th percentile. Cognitive skill is the Enlistment Test Score on cognitive ability. 
Figure 3.6. Non-cognitive skill and height.

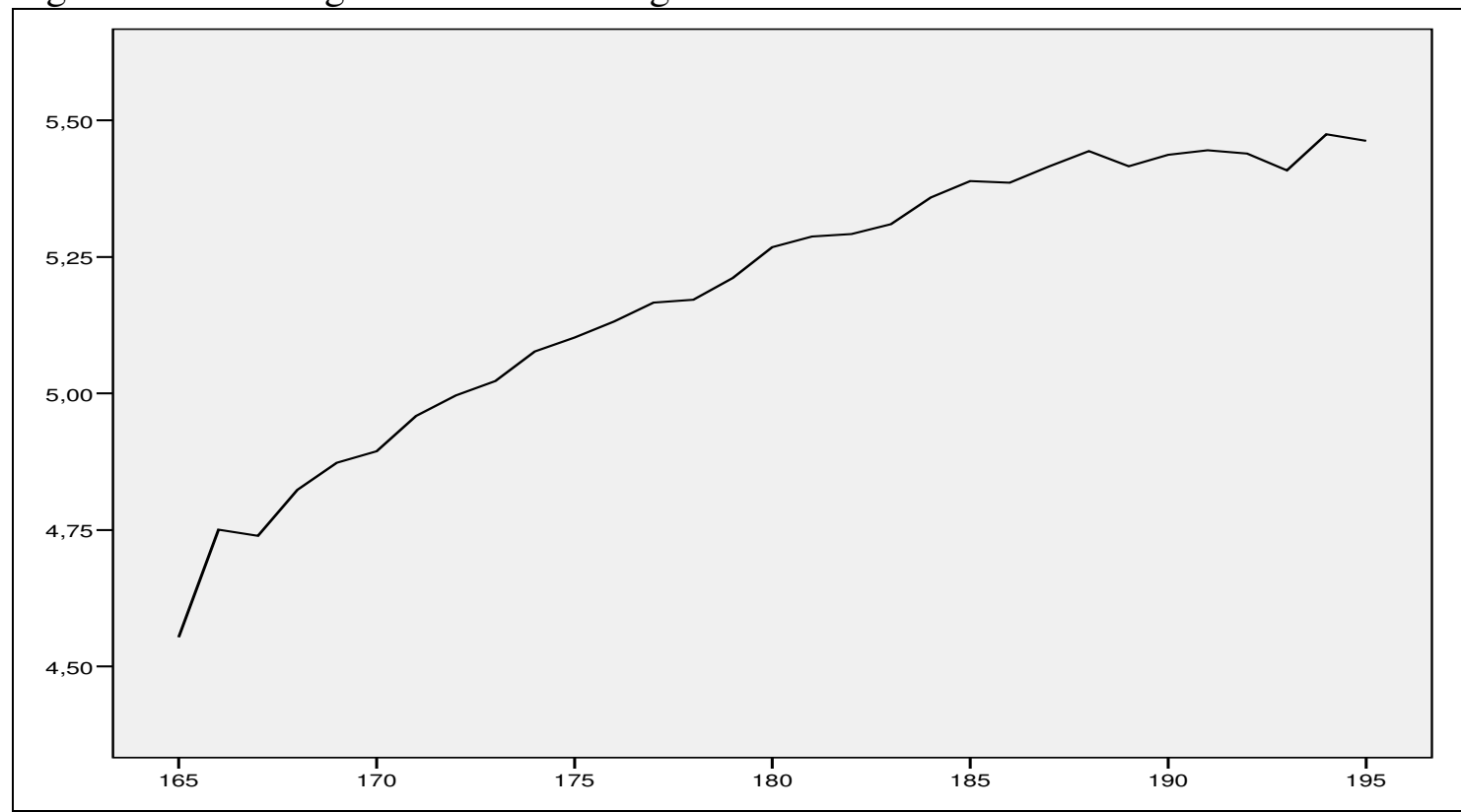

Note: The Height variable has been trimmed at the 1st and 99th percentile. Non-cognitive skill is the psychological evaluation when enlisting.

Figure 3.7a. Physical capacity (maximum work capacity) and height

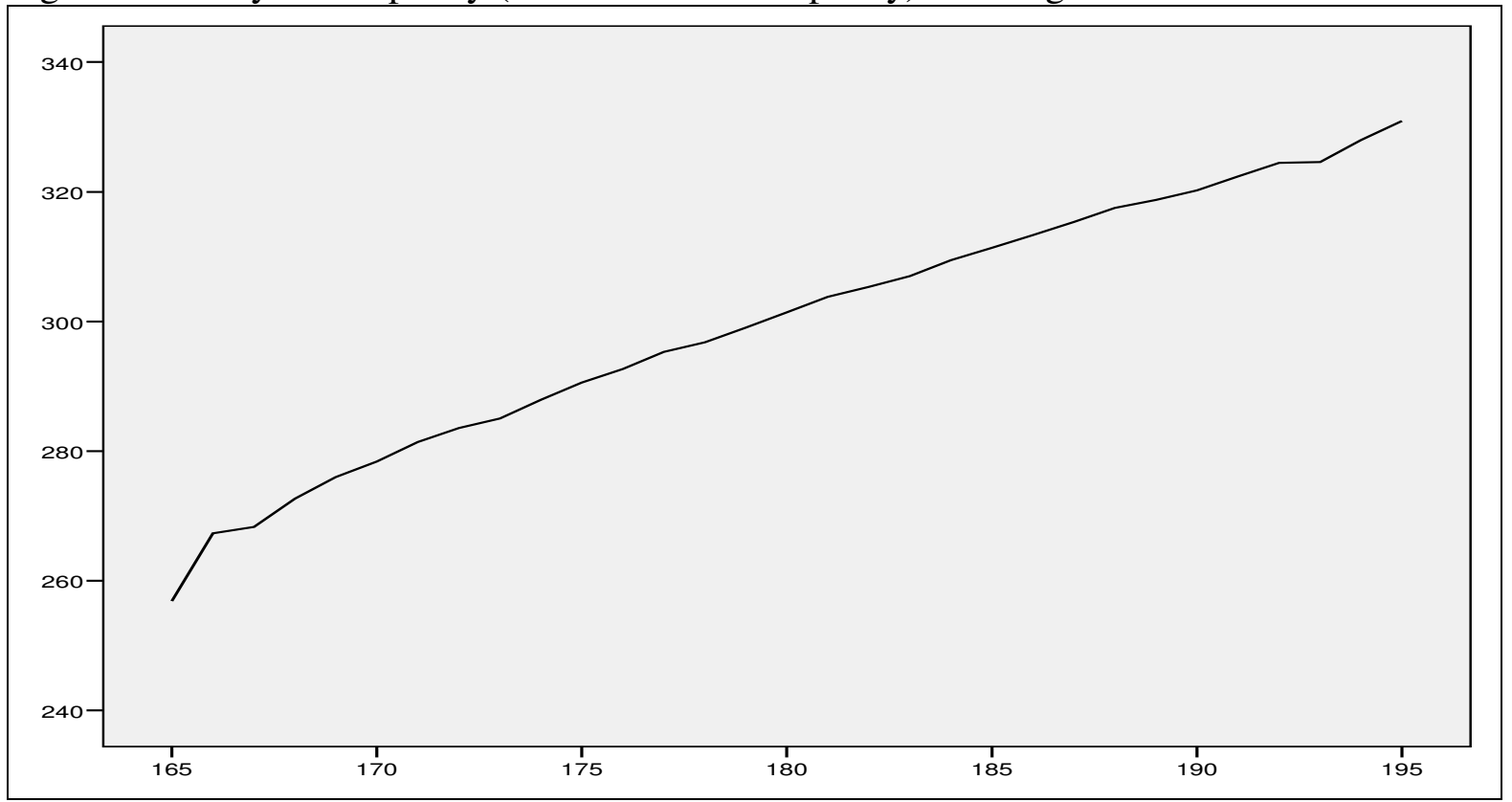

Note: The Height variable has been trimmed at the 1st and 99th percentile. One standard deviation in physical capacity is 50 units. 
Figure 3.7b. Physical capacity (handgrip strength) and height

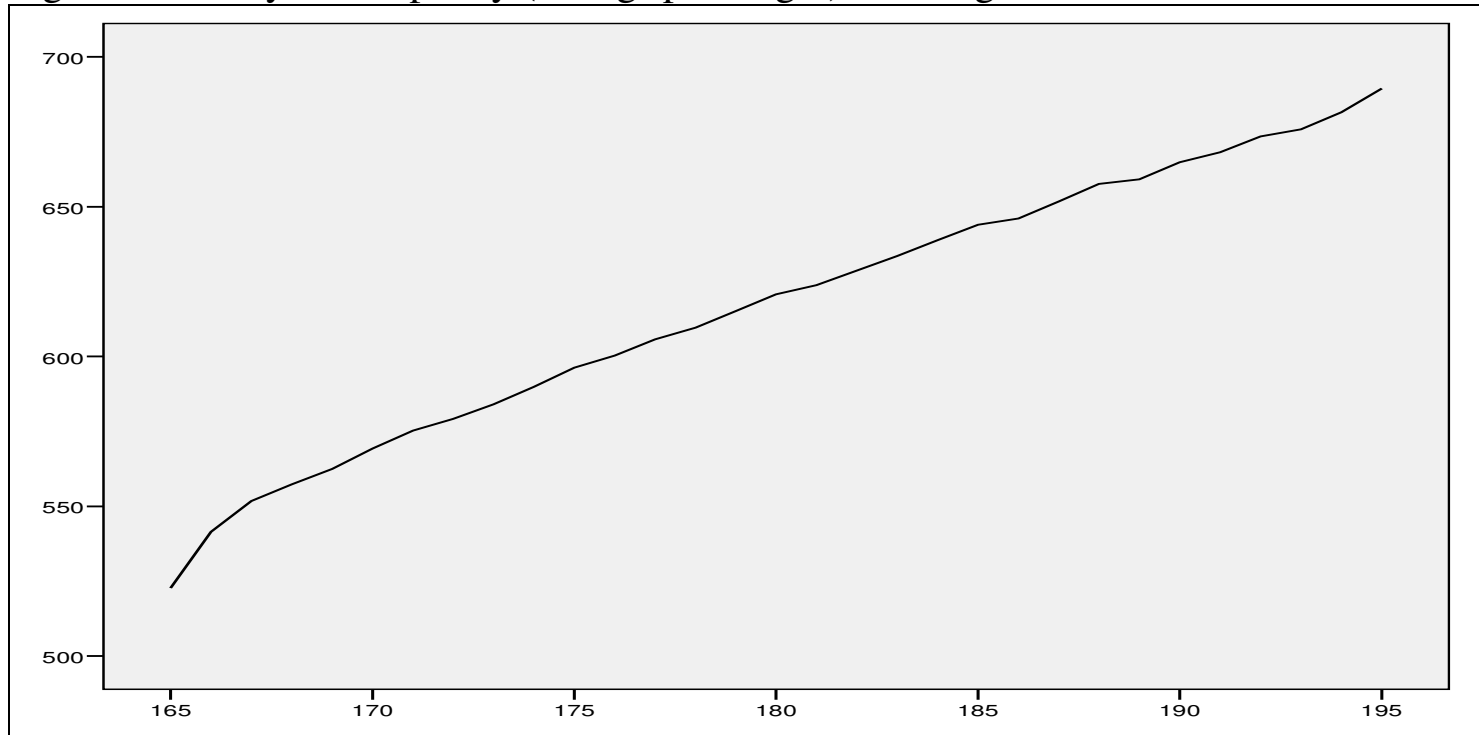

Note: The Height variable has been trimmed at the 1st and 99th percentile. One standard deviation in physical capacity is 100 units.

Figure 4.1. The height premium along the earnings distribution. Quantile regressions.

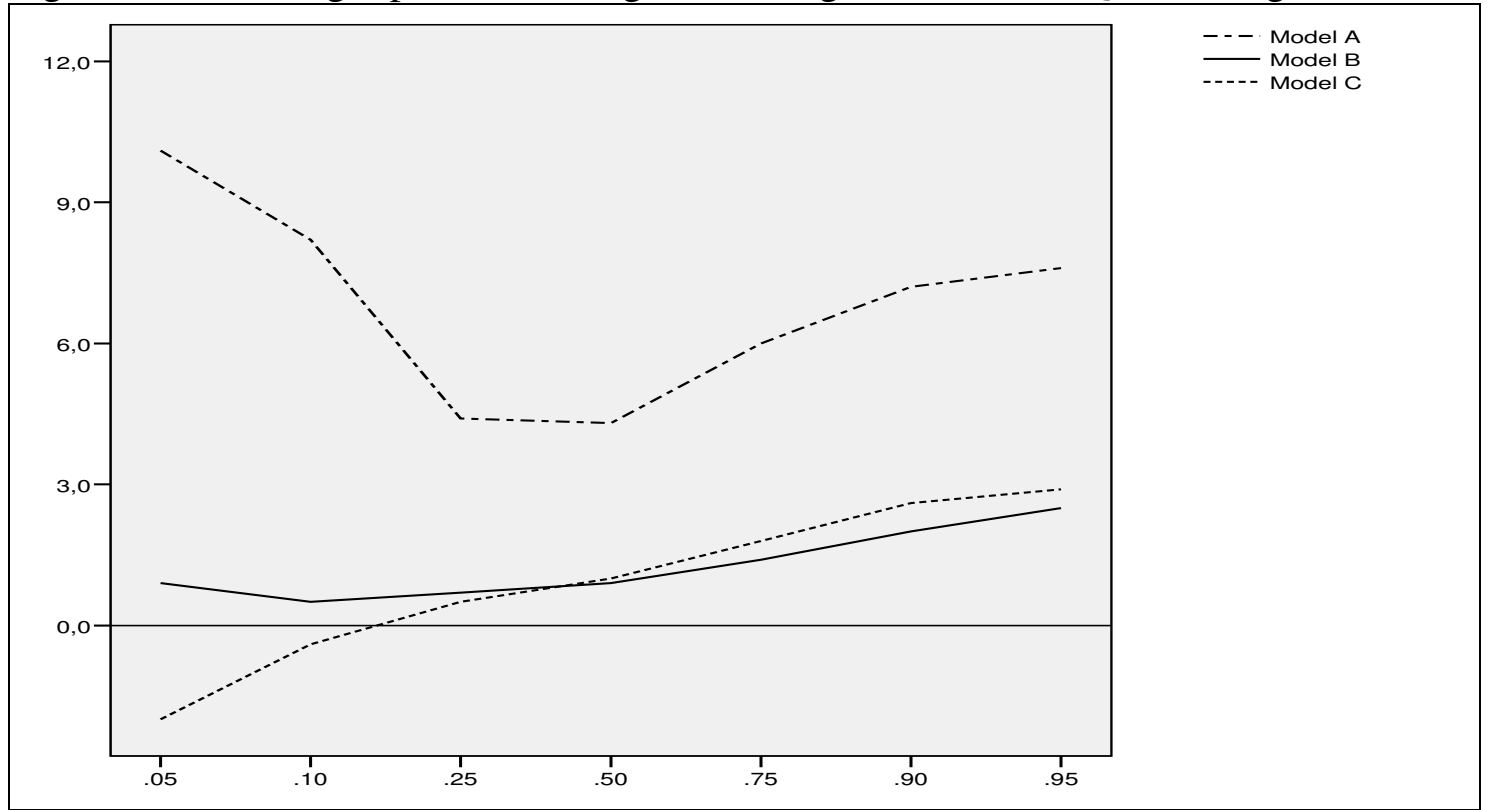

Note: The height premium in the graph should be interpreted as the change in earnings associated with a ten centimeters increase in height at different percentiles of the earnings distribution. Model A includes only height and age as regressors, while Model B corresponds to the full model (Model I) in Table 4.1 and Model C corresponds to the model with the physical capacity variables (Model H) in Table 4.1. 


\section{Tables:}

Table 3.1. Descriptive statistics of the population divided at median height. Men 28-38 years old, 2003.

\begin{tabular}{lrrrr}
\hline Variable & \multicolumn{2}{c}{$-179 \mathrm{~cm}$} & \multicolumn{2}{c}{$180 \mathrm{~cm}-$} \\
\hline Height in cm & 174.4 & $(3.8)$ & 184.7 & $(4.0)$ \\
Logarithm annual earnings & 12.30 & $(0.79)$ & 12.36 & $(0.78)$ \\
& & & & \\
Age & 33.2 & $(3.2)$ & 33.0 & $(3.2)$ \\
Parental characteristics: & 11.04 & $(0.50)$ & 11.08 & $(0.50)$ \\
Father's (log) earnings & 9.82 & $(1.25)$ & 9.86 & $(1.23)$ \\
Mother's (log) earnings & 11.2 & $(2.2)$ & 11.4 & $(2.3)$ \\
Father's years of schooling & 11.2 & $(2.1)$ & 11.4 & $(2.3)$ \\
Mother's years of schooling & 5.0 & $(1.9)$ & 5.4 & $(1.9)$ \\
Cognitive skill: & 4.9 & $(1.8)$ & 5.2 & $(1.8)$ \\
Enlistment test score & & & & \\
Non-cognitive skill: & & & & \\
Psychological evaluation when enlisting & 288.55 & $(47.95)$ & 310.48 & $(50.76)$ \\
Physical capacity: & & & & \\
Maximum working capacity, & 591.38 & $(89.91)$ & 641.03 & $(95.84)$ \\
Maximum watts on stationary bike & & & & \\
Muscular strength, & 21.97 & $(2.92)$ & 21.82 & $(2.89)$ \\
Handgrip & & & 223,434 & \\
BMI & 225,268 & & & \\
Number of observations & & & & \\
\hline
\end{tabular}

Notes: Standard deviations in parentheses. The variables measuring cognitive skills, non-cognitive skills, and physical capacity are standardized when used in the empirical analysis. 
Table 4.1. The height premium disentangled. Men 28-38 years old, 2003. Logarithm of annual earnings. Total population data.

\begin{tabular}{|c|c|c|c|c|c|c|c|c|c|}
\hline Variable & A & B & C & $\mathrm{D}$ & $\mathrm{E}$ & $\mathrm{F}$ & G & $\mathrm{H}$ & I \\
\hline Height premium ( $\left.{ }^{*} 10\right):$ & $\begin{array}{l}0.062^{* * *} \\
(0.002)\end{array}$ & $\begin{array}{l}0.052^{\star * *} \\
(0.002)\end{array}$ & $\begin{array}{l}0.052^{\star * *} \\
(0.002)\end{array}$ & $\begin{array}{l}0.036^{* * *} \\
(0.002)\end{array}$ & $\begin{array}{l}0.033^{* * *} \\
(0.002)\end{array}$ & $\begin{array}{c}0.018^{* * *} \\
(0.002)\end{array}$ & $\begin{array}{l}0.035^{\star * *} \\
(0.002)\end{array}$ & $\begin{array}{l}0.010^{* * *} \\
(0.002)\end{array}$ & $\begin{array}{l}0.013^{\star * *} \\
(0.002)\end{array}$ \\
\hline \multicolumn{10}{|l|}{ Parental characteristics: } \\
\hline Father's (log) earnings & - & $\begin{array}{l}0.132^{\star \star *} \\
(0.003)\end{array}$ & $\begin{array}{l}0.131^{* * *} \\
(0.003)\end{array}$ & $\begin{array}{l}0.115^{* * *} \\
(0.003)\end{array}$ & $\begin{array}{l}0.106^{* * *} \\
(0.003)\end{array}$ & $\begin{array}{c}0.122^{* * *} \\
(0.003)\end{array}$ & $\begin{array}{l}0.133^{* * *} \\
(0.003)\end{array}$ & $\begin{array}{l}0.123^{* * *} \\
(0.003)\end{array}$ & $\begin{array}{l}0.100^{* \star *} \\
(0.003)\end{array}$ \\
\hline Mother's (log) earnings & - & $\begin{array}{c}0.001 \\
(0.001)\end{array}$ & $\begin{array}{c}0.001 \\
(0.001)\end{array}$ & $\begin{array}{l}0.000 \\
(0.001)\end{array}$ & $\begin{array}{l}-0.002 \\
(0.001)\end{array}$ & $\begin{array}{l}0.000 \\
(0.001)\end{array}$ & $\begin{array}{c}0.001 \\
(0.001)\end{array}$ & $\begin{array}{c}0.000 \\
(0.001)\end{array}$ & $\begin{array}{l}-0.002^{* \star *} \\
(0.001)\end{array}$ \\
\hline Father's years of schooling & - & $\begin{array}{l}0.007^{* \star *} \\
(0.001)\end{array}$ & $\begin{array}{l}0.006^{* * *} \\
(0.001)\end{array}$ & $\begin{array}{l}-0.003^{* * *} \\
(0.001)\end{array}$ & $\begin{array}{l}0.000 \\
(0.001)\end{array}$ & $\begin{array}{c}0.004^{* * *} \\
(0.001)\end{array}$ & $\begin{array}{l}0.007^{* * *} \\
(0.001)\end{array}$ & $\begin{array}{l}0.004^{* * *} \\
(0.001)\end{array}$ & $\begin{array}{c}-0.005^{\star * *} \\
(0.001)\end{array}$ \\
\hline Mother's years of schooling & - & $\begin{array}{l}0.008^{* * *} \\
(0.001)\end{array}$ & $\begin{array}{l}0.008^{* * *} \\
(0.001)\end{array}$ & $\begin{array}{l}-0.001^{*} \\
(0.001)\end{array}$ & $\begin{array}{l}0.002^{*} \\
(0.001)\end{array}$ & $\begin{array}{l}0.006^{* \star *} \\
(0.001)\end{array}$ & $\begin{array}{l}0.008^{* * *} \\
(0.001)\end{array}$ & $\begin{array}{l}0.006^{* * *} \\
(0.001)\end{array}$ & $\begin{array}{c}-0.003^{* * *} \\
(0.001)\end{array}$ \\
\hline BMI: & - & - & $\begin{array}{l}-0.002^{* * *} \\
(0.001)\end{array}$ & $\begin{array}{l}0.000 \\
(0.001)\end{array}$ & $\begin{array}{c}-0.004^{* * *} \\
(0.001)\end{array}$ & $\begin{array}{c}-0.010^{\star * *} \\
(0.001)\end{array}$ & $\begin{array}{c}-0.005^{\star \star \star} \\
(0.001)\end{array}$ & $\begin{array}{c}-0.011^{* * *} \\
(0.001)\end{array}$ & $\begin{array}{c}-0.005^{\star \star \star} \\
(0.001)\end{array}$ \\
\hline $\begin{array}{l}\text { Cognitive skill: } \\
\text { Enlistment test score }\end{array}$ & - & - & - & $\begin{array}{l}0.107^{* * *} \\
(0.001)\end{array}$ & - & - & - & - & $\begin{array}{l}0.069^{\star \star \star} \\
(0.001)\end{array}$ \\
\hline $\begin{array}{l}\text { Non-cognitive skill: } \\
\text { Psychological evaluation }\end{array}$ & - & - & - & - & $\begin{array}{l}0.135^{* * *} \\
(0.001)\end{array}$ & - & - & - & $\begin{array}{l}0.105^{\star \star *} \\
(0.002)\end{array}$ \\
\hline $\begin{array}{l}\text { Physical capacity: } \\
\text { Maximum working capacity, } \\
\text { Maximum watts on stationary bike }\end{array}$ & - & - & - & - & - & $\begin{array}{l}0.081^{* * *} \\
(0.003)\end{array}$ & - & $\begin{array}{l}0.078^{* * *} \\
(0.001)\end{array}$ & $\begin{array}{l}0.018^{* * *} \\
(0.001)\end{array}$ \\
\hline $\begin{array}{l}\text { Muscular strength, } \\
\text { Handgrip }\end{array}$ & - & - & - & - & - & - & $\begin{array}{l}0.033^{\star \star *} \\
(0.001)\end{array}$ & $\begin{array}{l}0.020^{\star * *} \\
(0.001)\end{array}$ & $\begin{array}{l}0.012^{\star * \star} \\
(0.001)\end{array}$ \\
\hline $\begin{array}{l}\text { Reduction (\%) in original } \\
\text { (Model C) Height premium }\end{array}$ & & & & 31 & 37 & 65 & 33 & 81 & 75 \\
\hline R2 & 0.02 & 0.03 & 0.03 & 0.04 & 0.05 & 0.04 & 0.03 & 0.04 & 0.06 \\
\hline
\end{tabular}

Notes: This table reports estimates from the (1) regression model: Log Earnings $=\mathrm{a}+\mathrm{b} *$ Height $+\mathrm{c} * \mathrm{X}+\mathrm{d} *$ Missing info + e. Model A only includes height and age fixed effects and is estimated using OLS. Model B adds BMI and Model C adds the parental variables. Model D adds cognitive skill, Model E adds noncognitive skill, while Models F through $\mathrm{H}$ add the physical capacity variables. Model I includes all variables. 
Table 4.2. The height premium disentangled. Men 28-38 years old, 2003. Logarithm of annual earnings. Siblings data.

\begin{tabular}{|c|c|c|c|c|c|c|c|c|c|}
\hline Variable & A & $B$ & C & $\mathrm{D}$ & $E$ & $F$ & $G$ & $\mathrm{H}$ & 1 \\
\hline Height premium ( $\left.{ }^{*} 10\right):$ & $\begin{array}{l}0.062^{\star * *} \\
(0.003)\end{array}$ & $\begin{array}{l}0.042^{\star \star *} \\
(0.006)\end{array}$ & $\begin{array}{l}0.042^{\star * *} \\
(0.006)\end{array}$ & $\begin{array}{l}0.028^{* * *} \\
(0.006)\end{array}$ & $\begin{array}{c}0.029^{* * *} \\
(0.006)\end{array}$ & $\begin{array}{l}0.021^{* * *} \\
(0.006)\end{array}$ & $\begin{array}{c}0.026^{\star * *} \\
(0.006)\end{array}$ & $\begin{array}{l}0.011^{*} \\
(0.006)\end{array}$ & $\begin{array}{c}0.008 \\
(0.006)\end{array}$ \\
\hline BMI: & - & - & $\begin{array}{l}-0.002^{* *} \\
(0.001)\end{array}$ & $\begin{array}{l}-0.002^{*} \\
(0.001)\end{array}$ & $\begin{array}{l}-0.004^{* * *} \\
(0.001)\end{array}$ & $\begin{array}{l}-0.007^{* * *} \\
(0.001)\end{array}$ & $\begin{array}{l}-0.005^{\star \star *} \\
(0.001)\end{array}$ & $\begin{array}{l}-0.009^{* * *} \\
(0.001)\end{array}$ & $\begin{array}{c}-0.005^{* * *} \\
(0.001)\end{array}$ \\
\hline $\begin{array}{l}\text { Cognitive skill: } \\
\text { Enlistment test score }\end{array}$ & - & - & - & $\begin{array}{l}0.101^{* * *} \\
(0.004)\end{array}$ & - & - & - & - & $\begin{array}{l}0.076^{* * *} \\
(0.004)\end{array}$ \\
\hline $\begin{array}{l}\text { Non-cognitive skill: } \\
\text { Psychological evaluation }\end{array}$ & - & - & - & - & $\begin{array}{l}0.094^{* * *} \\
(0.003)\end{array}$ & - & - & - & $\begin{array}{l}0.069^{* * *} \\
(0.004)\end{array}$ \\
\hline $\begin{array}{l}\text { Physical capacity: } \\
\text { Maximum working capacity, } \\
\text { Maximum watts on stationary bike }\end{array}$ & - & - & - & - & - & $\begin{array}{c}0.051^{* * *} \\
(0.003)\end{array}$ & - & $\begin{array}{c}0.048^{* * *} \\
(0.003)\end{array}$ & $\begin{array}{c}0.016^{* * *} \\
(0.003)\end{array}$ \\
\hline $\begin{array}{l}\text { Muscular strength, } \\
\text { Handgrip }\end{array}$ & - & - & - & - & - & - & $\begin{array}{c}0.028^{* * *} \\
(0.003)\end{array}$ & $\begin{array}{c}0.021^{* * *} \\
(0.003)\end{array}$ & $\begin{array}{l}0.014^{* * *} \\
(0.003)\end{array}$ \\
\hline
\end{tabular}

\begin{tabular}{lccccccccc}
$\begin{array}{l}\text { Reduction (\%) in original } \\
\text { (Model C) Height premium }\end{array}$ & & & 33 & 31 & 50 & 38 & 74 & 81 \\
\hline Sibling fixed effects & No & Yes & Yes & Yes & Yes & Yes & Yes & Yes & Yes \\
\hline R2 & 0.02 & 0.02 & 0.02 & 0.04 & 0.05 & 0.03 & 0.02 & 0.03 & 0.06 \\
\hline Number of cases & 145,210 & 145,210 & 145,210 & 145,210 & 145,210 & 145,210 & 145,210 & 145,210 & 145,210
\end{tabular}

Notes: This table reports estimates from the (2) regression model: Log Earnings $=\mathrm{a}+\mathrm{b} *$ Height $+\mathrm{c} * \mathrm{X}+\mathrm{d} *$ Missing info $+\mathrm{f}+\mathrm{e}$. Model A only includes height and age fixed effects and is estimated using OLS for the sibling sample. Model B adds sibling fixed effects and Model C adds BMI. Model D adds cognitive skill, Model E non-cognitive skill, while Models F through $\mathrm{H}$ add the physical capacity variables. Model I includes all variables. 
Table 4.3. The height premium disentangled. Men 28-38 years old, 2003.

Logarithm of annual earnings. Siblings data.

\begin{tabular}{|c|c|c|c|c|c|c|c|}
\hline Variable & $\mathrm{A}$ & $B$ & $\mathrm{C}$ & $\mathrm{D}$ & $E$ & $\mathrm{~F}$ & G \\
\hline Height premium $\left({ }^{*} 10\right)$ : & $\begin{array}{l}0.040^{* * *} \\
(0.009)\end{array}$ & $\begin{array}{l}0.031^{\star * *} \\
(0.009)\end{array}$ & $\begin{array}{l}0.008 \\
(0.009)\end{array}$ & $\begin{array}{c}0.001 \\
(0.009)\end{array}$ & $\begin{array}{l}0.026 * * * \\
(0.009)\end{array}$ & $\begin{array}{l}0.021^{* *} \\
(0.009)\end{array}$ & $\begin{array}{l}0.003 \\
(0.009)\end{array}$ \\
\hline BMI: & $\begin{array}{l}-0.002 \\
(0.002)\end{array}$ & $\begin{array}{l}-0.002 \\
(0.002)\end{array}$ & $\begin{array}{l}-0.010^{* * *} \\
(0.002)\end{array}$ & $\begin{array}{c}-0.009^{* * *} \\
(0.002)\end{array}$ & $\begin{array}{l}-0.005^{* * *} \\
(0.002)\end{array}$ & $\begin{array}{l}-0.004^{* *} \\
(0.002)\end{array}$ & $\begin{array}{l}-0.008^{* * *} \\
(0.002)\end{array}$ \\
\hline $\begin{array}{l}\text { Cognitive skill: } \\
\text { Enlistment test score }\end{array}$ & & $\begin{array}{l}0.112^{* * *} \\
(0.007)\end{array}$ & - & $\begin{array}{l}0.108^{* * *} \\
(0.007)\end{array}$ & - & $\begin{array}{l}0.044^{* * *} \\
(0.004)\end{array}$ & $\begin{array}{l}0.085^{\star * *} \\
(0.007)\end{array}$ \\
\hline $\begin{array}{l}\text { Physical capacity: } \\
\text { Maximum working capacity, } \\
\text { Maximum watts on stationary bike } \\
\text { Muscular strength, } \\
\text { Handgrip }\end{array}$ & & - & $\begin{array}{l}0.056^{* * *} \\
(0.005) \\
0.018^{* * *} \\
(0.005)\end{array}$ & $\begin{array}{l}0.051^{* * *} \\
(0.005) \\
0.019^{* * *} \\
(0.005)\end{array}$ & $\begin{array}{l}- \\
-\end{array}$ & - & $\begin{array}{l}0.030^{* * *} \\
(0.005) \\
0.013^{* * *} \\
(0.005)\end{array}$ \\
\hline $\begin{array}{l}\text { Leadership skill: } \\
\text { Enlistment leadership evaluation } \\
\text { score }\end{array}$ & & - & - & - & $\begin{array}{c}0.196 * * * \\
(0.009)\end{array}$ & $\begin{array}{l}0.175^{* * *} \\
(0.009)\end{array}$ & $\begin{array}{l}0.158^{* * *} \\
(0.009)\end{array}$ \\
\hline $\begin{array}{l}\text { Reduction (\%) in original } \\
\text { (Model A) Height premium }\end{array}$ & & 22.5 & 80 & 97.5 & 35 & 47.5 & 92.5 \\
\hline Sibling fixed effects & Yes & Yes & Yes & Yes & Yes & Yes & Yes \\
\hline $\mathrm{R} 2$ & 0.02 & 0.03 & 0.03 & 0.04 & 0.05 & 0.05 & 0.05 \\
\hline Number of cases & 93,037 & 93,037 & 93,037 & 93,037 & 93,037 & 93,037 & 93,037 \\
\hline
\end{tabular}

Notes: This table reports estimates from the regression model (2): $\log$ Earnings $=\mathrm{a}+\mathrm{b} * \mathrm{Height}+\mathrm{c} * \mathrm{X}+\mathrm{d} * \mathrm{Missing}$ info $+\mathrm{f}+\mathrm{e}$.

Models A, B, C and D correspond to Models C, D, G and H in Table 3.2, respectively. Models E through G then add the leadership skill variable. 


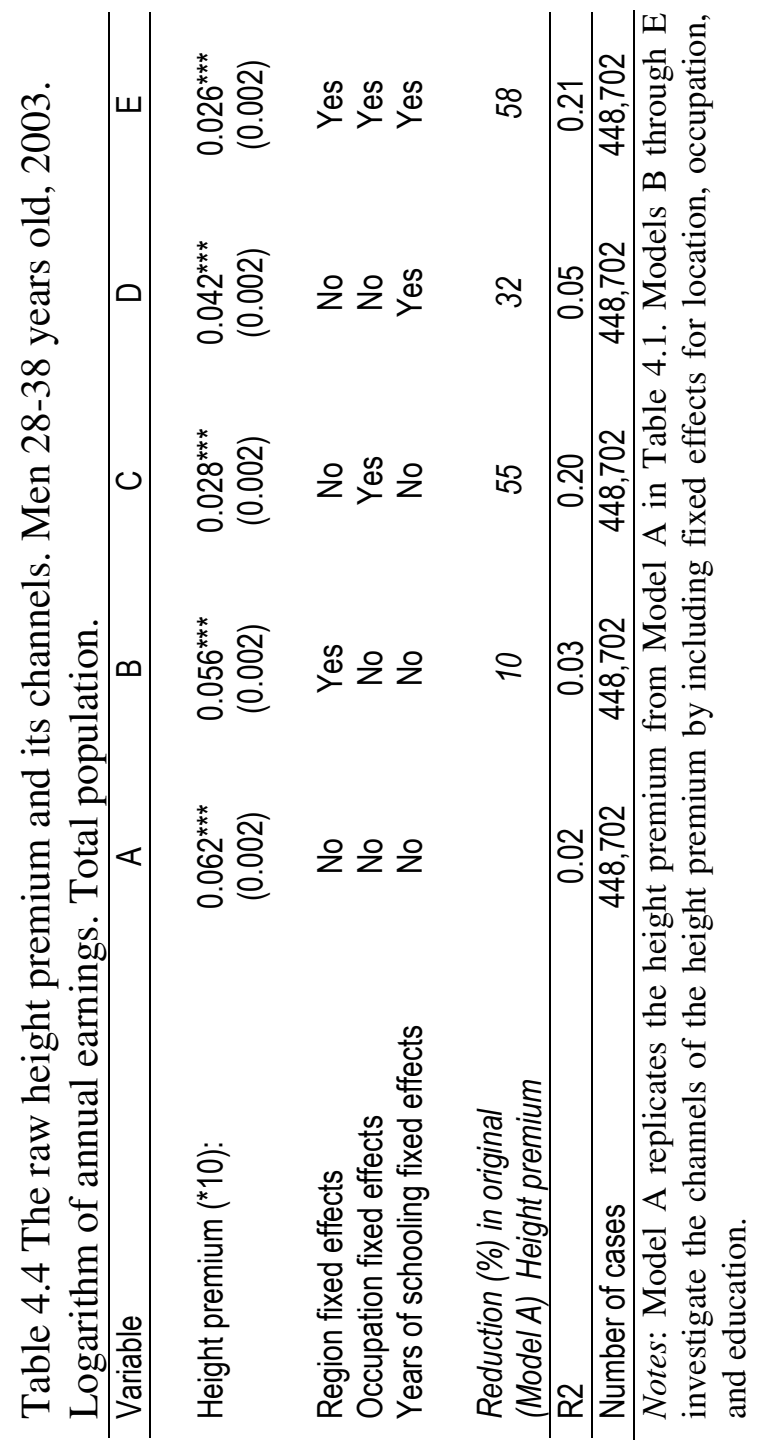


Table 4.5. The height premium (*10) and different outcome measures. Siblings. Men 28-38 years old, 2003. Logarithm of annual earnings.

\begin{tabular}{|c|c|c|c|c|c|}
\hline & (i) & (ii) & (iii) & (iv) & (v) \\
\hline Model B & $\begin{array}{l}0.042^{\star * *} \\
(0.006)\end{array}$ & $\begin{array}{c}0.040^{* * *} \\
(0.006)\end{array}$ & $\begin{array}{c}0.032^{* * *} \\
(0.003)\end{array}$ & $\begin{array}{c}0.046^{* * *} \\
(0.002)\end{array}$ & $\begin{array}{c}0.042^{* * *} \\
(0.006)\end{array}$ \\
\hline Model C & $\begin{array}{l}0.042^{* * *} \\
(0.006)\end{array}$ & $\begin{array}{l}0.040^{* * *} \\
(0.006)\end{array}$ & $\begin{array}{c}0.032^{\star * *} \\
(0.003)\end{array}$ & $\begin{array}{c}0.046^{* * *} \\
(0.002)\end{array}$ & $\begin{array}{c}0.042^{* * *} \\
(0.006)\end{array}$ \\
\hline Model D & $\begin{array}{c}0.028^{* * *} \\
(0.006)\end{array}$ & $\begin{array}{c}0.027^{* * *} \\
(0.006)\end{array}$ & $\begin{array}{c}0.021^{* * *} \\
(0.003)\end{array}$ & $\begin{array}{c}0.031^{* * *} \\
(0.006)\end{array}$ & $\begin{array}{c}0.031^{* * *} \\
(0.006)\end{array}$ \\
\hline Model E & $\begin{array}{c}0.029^{* * *} \\
(0.006)\end{array}$ & $\begin{array}{c}0.028^{* * *} \\
(0.006)\end{array}$ & $\begin{array}{c}0.024^{* * *} \\
(0.003)\end{array}$ & $\begin{array}{c}0.033^{* * *} \\
(0.006)\end{array}$ & $\begin{array}{c}0.031^{* * *} \\
(0.006)\end{array}$ \\
\hline Model H & $\begin{array}{c}0.011^{*} \\
(0.006)\end{array}$ & $\begin{array}{c}0.009 \\
(0.006)\end{array}$ & $\begin{array}{c}0.015^{\star * *} \\
(0.003)\end{array}$ & $\begin{array}{l}0.013^{* *} \\
(0.006)\end{array}$ & $\begin{array}{l}0.012^{*} \\
(0.007)\end{array}$ \\
\hline Model I & $\begin{array}{c}0.008 \\
(0.006)\end{array}$ & $\begin{array}{c}0.006 \\
(0.006)\end{array}$ & $\begin{array}{c}0.012^{* * *} \\
(0.003)\end{array}$ & $\begin{array}{c}0.009 \\
(0.006)\end{array}$ & $\begin{array}{c}0.009 \\
(0.006)\end{array}$ \\
\hline Sibling fixed effects & Yes & Yes & Yes & Yes & Yes \\
\hline Number of cases & 145,210 & 145,210 & 132,897 & 143,524 & 131,059 \\
\hline
\end{tabular}

Notes: Column (i) is the height premium replicated from Table 4.2, while Columns (ii) and (iii) show the height premium for those with top coded earnings and earnings above 100' SEK, respectively. Columns (iv) and (v) give the height premium when excluding social security benefits and enlistment "fakers", respectively. 
Table 4.6. The height premium $(* 10)$ at different percentiles of the earnings distribution. Men 28-38 years old, 2003.

\begin{tabular}{|c|c|c|c|}
\hline Percentile & $A$ & $B$ & C \\
\hline $5^{\text {th }}$ & $0.101^{* * *}(0.010)$ & $0.009 \quad(0.012)$ & $-0.020^{*}$ \\
\hline $10^{\text {th }}$ & $0.082^{* * *}(0.007)$ & $0.005 \quad(0.006)$ & -0.004 \\
\hline $25^{\text {th }}$ & $0.044^{* * *}(0.001)$ & $0.007^{\star \star *}(0.002)$ & $0.005^{\star * *}(0.002)$ \\
\hline Median & $0.043^{* * *}(0.001)$ & $0.009^{* * *}(0.001)$ & $0.010^{\star * *}(0.001)$ \\
\hline $75^{\text {th }}$ & $0.060^{* * *}(0.001)$ & $0.014^{* * *}(0.001)$ & $0.018^{* * *}(0.001)$ \\
\hline $90^{\text {th }}$ & $0.072^{* * *}(0.002)$ & $0.020^{\star * *}(0.001)$ & $0.026^{* * *}(0.001)$ \\
\hline $95^{\text {th }}$ & $0.076^{* * *}(0.002)$ & $0.025^{\star * *}(0.002)$ & $0.029^{\star * *}(0.002)$ \\
\hline
\end{tabular}

Number of cases

448,702

448,702

448,702

Notes: Model A gives the height premium from a quantile regression of log earnings on height in centimeters and on age. Model B includes the full set of control variables used in the empirical analysis (corresponds to Model A and I in Table 4.1). Model C adds BMI, parental characteristics and the physical capacity variables to Model A. 
Table 4.7. The height premium $(* 10)$ in different height ranges. Men 28-38 years old, 2003. Logarithm of annual earnings.

\begin{tabular}{|c|c|c|c|c|c|c|}
\hline & & Full sam & & & oling sam & \\
\hline & -174 & $175-185$ & 185- & -174 & $175-185$ & 185- \\
\hline Model B & $0.100^{* * *}$ & $0.049^{* * *}$ & 0.006 & 0.042 & $0.032^{* *}$ & -0.006 \\
\hline & $(0.009)$ & $(0.005)$ & $(0.009)$ & $(0.028)$ & $(0.015)$ & $(0.031)$ \\
\hline Model C & $0.100^{\star * *}$ & $0.049^{* * *}$ & 0.006 & 0.042 & $0.032^{* *}$ & -0.006 \\
\hline & $(0.009)$ & $(0.005)$ & $(0.009)$ & $(0.028)$ & $(0.015)$ & $(0.031)$ \\
\hline Model D & $0.075^{\star * *}$ & $0.033^{* * *}$ & -0.001 & 0.022 & 0.018 & -0.010 \\
\hline & $(0.009)$ & $(0.005)$ & $(0.009)$ & $(0.028)$ & $(0.015)$ & $(0.031)$ \\
\hline Model E & $0.065^{\star * *}$ & $0.029^{* * *}$ & 0.005 & 0.023 & 0.022 & -0.009 \\
\hline & $(0.009)$ & $(0.005)$ & $(0.009)$ & $(0.028)$ & $(0.015)$ & $(0.031)$ \\
\hline Model H & $0.040^{* * *}$ & 0.007 & $-0.021^{* *}$ & 0.009 & -0.003 & -0.030 \\
\hline & $(0.009)$ & $(0.005)$ & $(0.009)$ & $(0.029)$ & $(0.015)$ & $(0.031)$ \\
\hline Model I & $0.035^{\star * *}$ & 0.008 & -0.008 & 0.001 & -0.006 & -0.022 \\
\hline & $(0.009)$ & $(0.005)$ & $(0.009)$ & $(0.029)$ & $(0.015)$ & $(0.031)$ \\
\hline Sibling fixed effects & No & No & No & Yes & Yes & Yes \\
\hline Number of cases & 98,011 & 271,634 & 79,057 & 32,033 & 88,012 & 25,165 \\
\hline
\end{tabular}

Notes: Models B through I correspond to those in Table 4.1. 


\section{Appendix:}

Table A1. Variable List

\begin{tabular}{|c|c|}
\hline Variable & Definition of the variable \\
\hline Height (in cm) & Measured at age 18 when enlisting. \\
\hline Logarithm annual earnings & Annual earnings in 2003 from work or self-employment. \\
\hline Age & In 2003. 28-38 years old. Included as fixed effects in the regressions \\
\hline \multicolumn{2}{|l|}{ Parental characteristics: } \\
\hline Father's (log) earnings & Annual earnings in 1980 from work or self-employment \\
\hline Mother's (log) earnings & Annual earnings in 1980 from work or self-employment \\
\hline Father's years of schooling & Years of schooling, taking values from 9-18. Measured in 1999. \\
\hline Mother's years of schooling & Years of schooling, taking values from 9-18. Measured in 1999. \\
\hline Cognitive skill & Measured at age 18 when enlisting. The enlistment test score on a scale 1-9. \\
\hline Non-cognitive skill & Measured at age 18 when enlisting. Evaluated by a psychologist on a scale 1-9. \\
\hline Leadership skill & $\begin{array}{l}\text { Measured at age } 18 \text { when enlisting. Evaluated by a psychologist on a scale } 1-9 . \text { Only for } \\
\text { those scoring above } 5 \text { on the cognitive test. }\end{array}$ \\
\hline $\begin{array}{l}\text { Physical capacity: } \\
\text { Maximum working capacity }\end{array}$ & $\begin{array}{l}\text { Measured at age } 18 \text { when enlisting. During a } 5-10 \text { minute exercise the highest output } \\
\text { attained when riding on a stationary bike was measured in watts. }\end{array}$ \\
\hline Muscular strength & Measured at age 18 when enlisting. Measures handgrip strength of the strongest hand. \\
\hline BMI & $\begin{array}{l}\text { Measured at age } 18 \text { when enlisting. Calculated as a persons weight in } \mathrm{kg} \text { divided by the } \\
\text { square of his length in meters. }\end{array}$ \\
\hline \multicolumn{2}{|l|}{ Missing information on: } \\
\hline Father's (log) earnings & $\begin{array}{l}\text { Takes a value of } 1 \text { if missing information on father's log earnings and zero otherwise. If } \\
\text { missing the mean of father's log earnings is imputed. }\end{array}$ \\
\hline Mother's (log) earnings & $\begin{array}{l}\text { Takes a value of } 1 \text { if missing information on mother's log earnings and zero otherwise. If } \\
\text { missing, the mean of mother's log earnings is imputed. }\end{array}$ \\
\hline Father's years of schooling & $\begin{array}{l}\text { Takes a value of } 1 \text { if missing information on father's years of schooling and zero } \\
\text { otherwise. If missing, the mean of father's years of schooling is imputed. }\end{array}$ \\
\hline Mother's years of schooling & $\begin{array}{l}\text { Takes a value of } 1 \text { if missing information on mother's years of schooling and zero } \\
\text { otherwise. If missing, the mean of mother's years of schooling is imputed. }\end{array}$ \\
\hline $\begin{array}{l}\text { Maximum watts on stationary } \\
\text { bike }\end{array}$ & $\begin{array}{l}\text { Takes a value of } 1 \text { if missing information on maximum watts on stationary bike and zero } \\
\text { otherwise. If missing, a } 0 \text { is imputed since the variable is standardized. }\end{array}$ \\
\hline Handgrip strength & $\begin{array}{l}\text { Takes a value of } 1 \text { if missing information on handgrip strength and zero otherwise. If } \\
\text { missing, a } 0 \text { is imputed since the variable is standardized }\end{array}$ \\
\hline BMI & $\begin{array}{l}\text { Takes a value of } 1 \text { if missing information on the persons weight and zero otherwise. If } \\
\text { missing, the mean of BMl is imputed. }\end{array}$ \\
\hline Non-cognitive skill & $\begin{array}{l}\text { Takes a value of } 1 \text { if missing information on the persons weight and zero otherwise. If } \\
\text { missing, a } 0 \text { is imputed since the variable is standardized }\end{array}$ \\
\hline
\end{tabular}


Table A2. Descriptive statistics of the population. Men 28-38 years old, 2003. Total population and siblings.

\begin{tabular}{|c|c|c|}
\hline Variable & $\begin{array}{c}\text { Total } \\
\text { population }\end{array}$ & Siblings \\
\hline Height (in cm) & $\begin{array}{l}179.5 \\
(6.5)\end{array}$ & $\begin{array}{l}179.5 \\
(6.5)\end{array}$ \\
\hline Logarithm annual earnings & $\begin{array}{l}12.33 \\
(.79)\end{array}$ & $\begin{array}{l}12.34 \\
(.76)\end{array}$ \\
\hline Age & $\begin{array}{l}33.1 \\
(3.2)\end{array}$ & $\begin{array}{l}33.1 \\
(3.0)\end{array}$ \\
\hline \multicolumn{3}{|l|}{ Parental characteristics: } \\
\hline Father's (log) earnings & $\begin{array}{l}11.06 \\
(.50)\end{array}$ & $\begin{array}{l}11.07 \\
(.50)\end{array}$ \\
\hline Mother's (log) earnings & $\begin{array}{c}9.84 \\
(1.24)\end{array}$ & $\begin{array}{c}9.66 \\
(1.35)\end{array}$ \\
\hline Father's years of schooling & $\begin{array}{l}11.30 \\
(2.26)\end{array}$ & $\begin{array}{l}11.29 \\
(2.30)\end{array}$ \\
\hline Mother's years of schooling & $\begin{array}{l}11.32 \\
(2.20)\end{array}$ & $\begin{array}{l}11.33 \\
(2.21)\end{array}$ \\
\hline Cognitive skill: & $\begin{array}{c}5.2 \\
(1.9)\end{array}$ & $\begin{array}{l}5.1 \\
(1.9)\end{array}$ \\
\hline Non-cognitive skill: & $\begin{array}{c}5.0 \\
(1.9)\end{array}$ & $\begin{array}{l}5.0 \\
(1.9)\end{array}$ \\
\hline \multicolumn{3}{|l|}{ Physical capacity: } \\
\hline $\begin{array}{l}\text { Maximum working capacity, } \\
\text { maximum watts on stationary bike }\end{array}$ & $\begin{array}{l}299.47 \\
(50.57)\end{array}$ & $\begin{array}{l}300.79 \\
(50.69)\end{array}$ \\
\hline $\begin{array}{l}\text { Muscular strength, } \\
\text { handgrip } \\
\text { BMI: }\end{array}$ & $\begin{array}{c}616.10 \\
(96.17) \\
21.90 \\
(2.91)\end{array}$ & $\begin{array}{c}616.98 \\
(96.28) \\
21.85 \\
(2.86)\end{array}$ \\
\hline \multicolumn{3}{|l|}{ Missing information in (shares): } \\
\hline Father's (log) earnings & .03 & .02 \\
\hline Mother's (log) earnings & .11 & .13 \\
\hline Father's years of schooling & .12 & .09 \\
\hline Mother's years of schooling & .05 & .04 \\
\hline Maximum watts on stationary bike & .00 & .00 \\
\hline Handgrip strength & .00 & .00 \\
\hline BMI & .00 & .00 \\
\hline Non-cognitive skill & & \\
\hline Number of observations & 448,702 & 145,210 \\
\hline
\end{tabular}

Notes: Standard deviations in parentheses. The variables measuring cognitive skill, non-cognitive skill, and physical capacity are standardized when used in the empirical analysis. 
Table A3. Correlations among explanatory variables. Total population. Men 28-38 years old, 2003.

\begin{tabular}{|c|c|c|c|c|c|c|c|}
\hline Variable & A & $B$ & $C$ & $D$ & $E$ & $\mathrm{~F}$ & G. \\
\hline A. Height & 1 & $0.13^{*}$ & $0.11^{*}$ & $0.27^{*}$ & $0.33^{*}$ & $-0.03^{*}$ & $0.05^{*}$ \\
\hline B. Cognitive skill & $0.13^{*}$ & 1 & $0.36^{*}$ & $0.19^{*}$ & $0.02^{*}$ & $-0.08^{\star}$ & $0.15^{*}$ \\
\hline C. Non-cognitive skill & $0.11^{*}$ & $0.36^{*}$ & 1 & $0.44^{*}$ & $0.16^{*}$ & $0.02^{*}$ & $0.19^{*}$ \\
\hline D.. Max. working capacity & $0.27^{\star}$ & $0.19^{*}$ & $0.44^{*}$ & 1 & $0.29^{*}$ & $0.26^{*}$ & $0.10^{*}$ \\
\hline E. Muscular strength & $0.33^{*}$ & $0.02^{*}$ & $0.16^{*}$ & $0.29^{*}$ & 1 & $0.28^{*}$ & $0.04^{*}$ \\
\hline F. BMl & $-0.03^{*}$ & $-0.08^{*}$ & $0.02^{*}$ & $0.26^{*}$ & $0.28^{*}$ & 1 & $-0.02^{\star}$ \\
\hline G. Log Earnings & $0.05^{\star}$ & $0.15^{*}$ & $0.19^{*}$ & $0.10^{*}$ & $0.04^{*}$ & $-0.02^{*}$ & 1 \\
\hline
\end{tabular}

Notes: *) correlation is significant at the 0.01 level

Table A4. The raw height premium and its channels. Men 28-38 years old, 2003.

Logarithm of annual earnings. Siblings data.

\begin{tabular}{|c|c|c|c|c|c|}
\hline Variable & $\mathrm{A}$ & $\mathrm{B}$ & $\mathrm{C}$ & $\mathrm{D}$ & $E$ \\
\hline Height premium (*10): & $\begin{array}{c}0.042^{* * *} \\
(0.006)\end{array}$ & $\begin{array}{c}0.040^{* * *} \\
(0.006)\end{array}$ & $\begin{array}{c}0.025^{* * *} \\
(0.005)\end{array}$ & $\begin{array}{c}0.037^{* * *} \\
(0.006)\end{array}$ & $\begin{array}{c}0.025^{* * *} \\
(0.005)\end{array}$ \\
\hline Region fixed effects & No & Yes & No & No & Yes \\
\hline Occupation fixed effects & No & No & Yes & No & Yes \\
\hline $\begin{array}{l}\text { Years of schooling fixed } \\
\text { effects }\end{array}$ & No & No & No & Yes & Yes \\
\hline $\mathrm{R} 2$ & 0.02 & 0.03 & 0.20 & 0.04 & 0.20 \\
\hline No of cases & 145,210 & 145,210 & 145,210 & 145,210 & 145,210 \\
\hline
\end{tabular}

